\title{
Synthesis of the 3-Aza-[7]- paracyclophane Core of Haouamine A and B
}

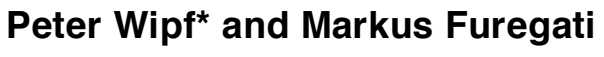 \\ Department of Chemistry, University of Pittsburgh, Pittsburgh, Pennsylvania \\ 15260 \\ pwipf+@pitt.edu
}

Experimental procedures and spectral data for all new compounds, including copies of ${ }^{1} \mathrm{H}$ and ${ }^{13} \mathrm{C}$ NMR spectra. CIF file for the x-ray structure of $\mathbf{1 7} \cdot \mathbf{H C l}$. 
General Methods. All moisture-sensitive reactions were performed under an atmosphere of $\mathrm{N}_{2}$ and glassware was flame dried under vacuum prior to use. $\mathrm{Et}_{2} \mathrm{O}$, THF and 1,4-dioxane were dried by distillation over $\mathrm{Na}$ /benzophenone and TEA was dried by distillation over $\mathrm{CaH}_{2}$. Toluene and DCM were purified by filtration through activated alumina. Unless stated otherwise, solvents or reagents were used as received. Analytical thin layer chromatography (TLC) was performed on pre-coated silica gel 60 F-254 plates (particle size 0.040-0.055 mm, 230-400 mesh) and visualization was accomplished with a $254 \mathrm{~nm}$ UV light and/or by staining with PAA reagent (2.5 mL of $p$-anisaldehyde, $3.5 \mathrm{~mL}$ of conc. $\mathrm{H}_{2} \mathrm{SO}_{4}, 2.0 \mathrm{~mL}$ of conc. $\mathrm{HOAc}, 92 \mathrm{~mL}$ of $95 \%$ EtOH). Gas chromatograms were obtained on a Hewlett Packard HP 6890 Series GC System with an Alltech-column (phase: $\mathrm{EC}^{\mathrm{TM}}-1$, length: $30 \mathrm{~m}$, ID: $0.32 \mathrm{~mm}$, film thickness: $0.25 \mu \mathrm{m}$ ) and FID. The following method was used: flow rate: $1.0 \mathrm{~mL} / \mathrm{min}, 70->240^{\circ} \mathrm{C}\left(15^{\circ} \mathrm{C} / \mathrm{min}\right), 5 \mathrm{~min}$ hold, $240->300^{\circ} \mathrm{C}\left(25^{\circ} \mathrm{C} / \mathrm{min}\right), 12 \mathrm{~min}$ hold time. NMR spectra were recorded at $300 \mathrm{MHz}\left({ }^{1} \mathrm{H}\right)$ and $75 \mathrm{MHz}\left({ }^{13} \mathrm{C}\right)$ using a Bruker AVANCE $300 \mathrm{MHz}$ spectrometer at $\mathrm{rt}$ unless stated otherwise. Chemical shifts $(\delta)$ are reported as follows: chemical shift, multiplicity $(\mathrm{s}=$ singlet, $\mathrm{d}=$ dublet, $\mathrm{t}$ $=$ triplet, $\mathrm{q}=$ quartet, $\mathrm{m}=$ multiplet, $\mathrm{b}=$ broad), coupling constants and integration. IR spectra were obtained on a Nicolet AVATAR 360 FT-IR E.S.P. spectrometer. Mass spectra were obtained on a Micromass Autospec double focusing instrument. Melting points were obtained using a MelTemp melting point apparatus and are reported uncorrected.

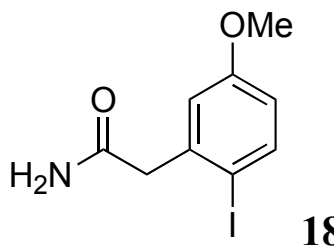

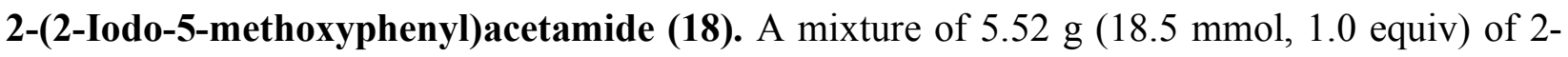
iodo-5-methoxyphenylacetic acid and $10.8 \mathrm{~mL}$ (148 mmol, 8.0 equiv) of $\mathrm{SOCl}_{2}$ was heated at reflux for $2.5 \mathrm{~h}$. The $\mathrm{SOCl}_{2}$ was distilled off, $15 \mathrm{~mL}$ of dry toluene was added, and the solvent was removed. The residue was dissolved in $15 \mathrm{~mL}$ of dry toluene, and the solvent was again removed in vacuo. The crude acid chloride was dissolved in $20 \mathrm{~mL}$ of dry THF and added under vigorous stirring at $0{ }^{\circ} \mathrm{C}$ to a mixture of $160 \mathrm{~mL}$ of THF and $12 \mathrm{~mL}$ (185 mmol, 10 equiv) of a $29 \% \mathrm{NH}_{4} \mathrm{OH}$ solution. After stirring at $\mathrm{rt}$ for $1 \mathrm{~h}$, the solvent was removed, water was added, and mixture was heated for 10 min while stirring. The suspension was cooled in an ice bath, filtered and the residue was washed with water. The crude amide was dried by adding dry toluene $(3 \times 15$ 
$\mathrm{mL}$ ) and distilling it off. Amide 18 (5.34 g, 97\%) was obtained as very fine, short, colorless needles: $\mathrm{R}_{\mathrm{f}} 0.13$ (hexanes/EtOAc, 7:3); GC $t_{\mathrm{R}} 12.25 \min \left(98.3 \%\right.$ ); Mp 181.0-183.6 ${ }^{\circ} \mathrm{C}$; FTIR (KBr) 3374, 3187, 3013, 2973, 2937, 2839, 1661, 1635, 1590, 1564, 1470, 1422, 1411, 1400, $1303,1288,1257,1204,1185,1164,1133,1050,1008,948,890,863,818 \mathrm{~cm}^{-1} ;{ }^{1} \mathrm{H}$ NMR $\left(\right.$ DMSO-d $\left._{6}\right) \delta 7.71(\mathrm{~d}, J=8.6 \mathrm{~Hz}, 1 \mathrm{H}), 7.42(\mathrm{bs}, 1 \mathrm{H}), 7.02(\mathrm{bs}, 1 \mathrm{H}), 6.98(\mathrm{~d}, J=2.9 \mathrm{~Hz}, 1 \mathrm{H})$, $6.68(\mathrm{dd}, J=8.6,3.0 \mathrm{~Hz}, 1 \mathrm{H}), 3.77$ (s, $3 \mathrm{H}), 3.55$ (s, $2 \mathrm{H}) ;{ }^{13} \mathrm{C}$ NMR $\left(\mathrm{DMSO}_{6}\right) \delta$ 171.7, 160.3, 141.5, 140.1, 118.2, 115.3, 91.1, 56.2, 47.5; HRMS (EI) $\mathrm{m} / z$ calcd for $\mathrm{C}_{9} \mathrm{H}_{10} \mathrm{INO}_{2} 290.9756$, found 290.9761 .

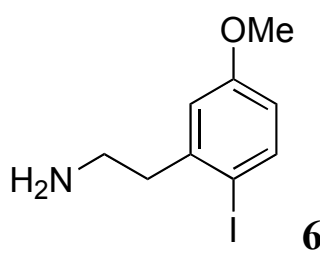

2-(2-Iodo-5-methoxyphenyl)ethanamine (6). To a suspension of $5.30 \mathrm{~g}$ (17.9 mmol, 1.0 equiv) of amide 18 in $50 \mathrm{~mL}$ of dry THF was added $55.4 \mathrm{~mL}(55.4 \mathrm{mmol}, 3.0$ equiv) of a $1.0 \mathrm{M}$ $\mathrm{BH}_{3} \cdot \mathrm{THF}$ solution in THF. The clear solution was heated at reflux for $3 \mathrm{~h}$. After hydrolysis with $5 \mathrm{~mL}$ of $\mathrm{H}_{2} \mathrm{O}$ at $0{ }^{\circ} \mathrm{C}$ and addition of $20 \mathrm{~mL}$ of conc. $\mathrm{HCl}$ solution, the reaction mixture was heated at reflux for $5 \mathrm{~min}$. After removal of two thirds of the solvent and subsequent addition of a solution of $15 \mathrm{~g} \mathrm{NaOH}$ in $50 \mathrm{~mL}$ of $\mathrm{H}_{2} \mathrm{O}$, the mixture was extracted with $\mathrm{Et}_{2} \mathrm{O}$, the combined organic phases were dried $\left(\mathrm{MgSO}_{4}\right)$ and the solvent was removed to yield $5.09 \mathrm{~g}(95 \%)$ of a partly crystalline oil was obtained. The product contained approximately $5 \%$ of starting material 18 according to $\mathrm{GC}$ analysis: $\mathrm{R}_{\mathrm{f}} 0.04$ (hexanes/EtOAc, 7:3); GC $t_{\mathrm{R}} 10.52$ min (94.0\%); FTIR (neat) 3361, 3164, 3061, 3000, 2935, 2835, 1681, 1590, 1567, 1468, 1442, 1411, 1396, 1293, 1238, 1191, 1163, 1137, 1051, 1005, 922, 848, 802, $589 \mathrm{~cm}^{-1} ;{ }^{1} \mathrm{H}$ NMR $\left(\mathrm{CDCl}_{3}\right) \delta 7.66(\mathrm{~d}, J=$ $8.7 \mathrm{~Hz}, 1 \mathrm{H}), 6.79$ (d, $J=3.0 \mathrm{~Hz}, 1 \mathrm{H}), 6.51$ (dd, $J=8.7,3.1 \mathrm{~Hz}, 1 \mathrm{H}), 3.76(\mathrm{~s}, 3 \mathrm{H}), 2.98-2.91$ (m, $2 \mathrm{H}), 2.88-2.80(\mathrm{~m}, 2 \mathrm{H}), 1.54(\mathrm{~s}, 2 \mathrm{H}) ;{ }^{13} \mathrm{C} \mathrm{NMR}\left(\mathrm{CDCl}_{3}\right) \delta 160.1,143.5,140.1,116.2$, 114.1, 89.4, 55.5, 44.9, 42.5; HRMS (EI) $m / z$ calcd for $\mathrm{C}_{8} \mathrm{H}_{8} \mathrm{IO} 246.9620\left(M-\mathrm{CH}_{4} \mathrm{~N}\right)$, found 246.9622 . 


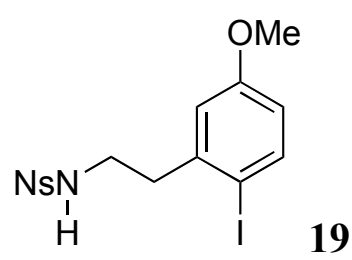

$\mathrm{N}$-Nosyl-2-(2-iodo-5-methoxyphenyl)ethanamine (19). To an ice cooled solution of $5.06 \mathrm{~g}$ (17.2 mmol, 1.0 equiv) of 6 and $3.60 \mathrm{~mL}$ ( $25.7 \mathrm{mmol}, 1.5$ equiv) of TEA in $60 \mathrm{~mL}$ of DCM was added a solution of $4.71 \mathrm{~g}$ ( $20.6 \mathrm{mmol}, 1.2$ equiv) of 2-nitrobenzenesulfonylchloride in $16 \mathrm{~mL}$ of DCM. After stirring at $\mathrm{rt}$ for $19 \mathrm{~h}$, the reaction mixture was washed with $100 \mathrm{~mL}$ of $\mathrm{H}_{2} \mathrm{O}$ and the aqueous phase was extracted with $25 \mathrm{~mL}$ of DCM. The combined organic phases were dried $\left(\mathrm{MgSO}_{4}\right)$ and concentrated. The crude product was dissolved in a hot mixture of $25 \mathrm{~mL}$ of hexanes/EtOAc (7:3) and $75 \mathrm{~mL}$ of DCM. The solution was concentrated until an estimated amount of $30 \mathrm{~mL}$ of solvent remained, and the mixture was allowed to cool to rt while stirring. After crystallization (seeding if necessary), the mixture was cooled in an ice bath for $2 \mathrm{~h}$ and the product was filtered off. After washing with cold hexanes/EtOAc (7:3) and drying in vacuo, 5.93 $\mathrm{g}(72 \%)$ of 19 as yellow fine needles were obtained: $\mathrm{R}_{\mathrm{f}} 0.23$ (hexanes/EtOAc, 7:3); Mp 140.5$142.5^{\circ} \mathrm{C}$ (hexanes/EtOAc/DCM); FTIR (KBr) 3346, 3099, 2995, 2942, 2895, 2835, 1661, 1591, 1573, 1532, 1478, 1444, 1410, 1357, 1348, 1327, 1305, 1239, 1162, 1119, 1079, 1037, 1007, $983,934,884,863,810,784,736,690,653,632,592,563 \mathrm{~cm}^{-1} ;{ }^{1} \mathrm{H} \mathrm{NMR}\left(\mathrm{CDCl}_{3}\right) \delta 8.15-8.09$ (m, $1 \mathrm{H}), 7.87-7.81(\mathrm{~m}, 1 \mathrm{H}), 7.75-7.68(\mathrm{~m}, 2 \mathrm{H}), 7.59(\mathrm{~d}, J=8.7 \mathrm{~Hz}, 1 \mathrm{H}), 6.74(\mathrm{~d}, J=3.0 \mathrm{~Hz}, 1$ H), 6.49 (dd, $J=8.7,3.0 \mathrm{~Hz}, 1 \mathrm{H}), 5.37$ (t, $J=5.9 \mathrm{~Hz}, 1 \mathrm{H}), 3.75$ (s, $3 \mathrm{H}), 3.40$ (q, $J=6.8 \mathrm{~Hz}, 2$ H), $2.93(\mathrm{t}, J=7.1 \mathrm{~Hz}, 2 \mathrm{H}) ;{ }^{13} \mathrm{C} \mathrm{NMR}\left(\mathrm{CDCl}_{3}\right) \delta 160.2,148.0,141.2,140.3,134.0,133.7,133.1$, 131.2, 125.6, 116.5, 115.0, 88.7, 55.6, 43.6, 41.0; HRMS (EI) $\mathrm{m} / z$ calcd for $\mathrm{C}_{15} \mathrm{H}_{15} \mathrm{IN}_{2} \mathrm{O}_{5} \mathrm{~S}$ 461.9746, found 461.9741 .

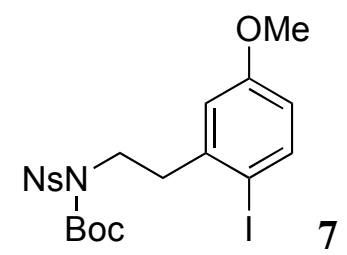

$\boldsymbol{N}$-Boc- $\boldsymbol{N}$-nosyl-2-(2-iodo-5-methoxyphenyl)ethanamine (7). To a suspension of $5.86 \mathrm{~g}$ (12.2 mmol, 1.0 equiv) of 19 in $65 \mathrm{~mL}$ of DCM was added a solution of $3.29 \mathrm{~g}$ (14.6 mmol, 1.2 equiv) of $\mathrm{Boc}_{2} \mathrm{O}$ in $15 \mathrm{~mL}$ of DCM and $0.30 \mathrm{~g}$ ( $2.4 \mathrm{mmol}, 0.2$ equiv) of DMAP. After a few minutes, a clear, bright yellow solution was obtained, which was stirred at $\mathrm{rt}$ for $2 \mathrm{~h}$. The reaction mixture 
was washed with $50 \mathrm{~mL}$ of $\mathrm{H}_{2} \mathrm{O}$ and the organic phase was dried $\left(\mathrm{MgSO}_{4}\right)$ and concentrated. The residue was purified by chromatography on $\mathrm{SiO}_{2}$ (hexanes/EtOAc, 7:3). Trituration of the residue with $\mathrm{Et}_{2} \mathrm{O}$ led to slow crystallization, and $6.70 \mathrm{~g}(98 \%)$ of 7 was obtained as a slightly yellow solid: $\mathrm{R}_{\mathrm{f}} 0.29$ (hexanes/EtOAc, 7:3); Mp 101.5-103.2 ${ }^{\circ} \mathrm{C}$; FTIR (KBr) 3428, 2974, 2942, 1722 , 1592, 1571, 1473, 1444, 1395, 1366, 1311, 1251, 1240, 1154, 1122, 1063, 1038, 1005, 920, 854, 841, $810 \mathrm{~cm}^{-1} ;{ }^{1} \mathrm{H}$ NMR $\left(\mathrm{CDCl}_{3}\right) \delta 8.34-8.31(\mathrm{~m}, 1 \mathrm{H}), 7.74-7.71(\mathrm{~m}, 3 \mathrm{H}), 7.66(\mathrm{~d}, J=8.7 \mathrm{~Hz}, 1$ H), $6.99(\mathrm{~d}, J=3.0 \mathrm{~Hz}, 1 \mathrm{H}), 6.55(\mathrm{dd}, J=8.7,3.0 \mathrm{~Hz}, 1 \mathrm{H}), 4.05(\mathrm{t}, J=6.9 \mathrm{~Hz}, 2 \mathrm{H}), 3.79(\mathrm{~s}, 3$ $\mathrm{H}), 3.14(\mathrm{t}, J=6.9 \mathrm{~Hz}, 2 \mathrm{H}), 1.23(\mathrm{~s}, 9 \mathrm{H}) ;{ }^{13} \mathrm{C} \mathrm{NMR}\left(\mathrm{CDCl}_{3}\right) \delta 160.2,150.4,147.7,142.1,139.9$, 134.3, 133.7, 133.5, 131.9, 124.4, 116.2, 115.5, 89.2, 84.9, 55.5, 47.4, 41.6, 27.8; HRMS (EI) $m / z$ calcd for $\mathrm{C}_{20} \mathrm{H}_{23} \mathrm{IN}_{2} \mathrm{O}_{7} \mathrm{~S} 562.0271$, found 562.0278.

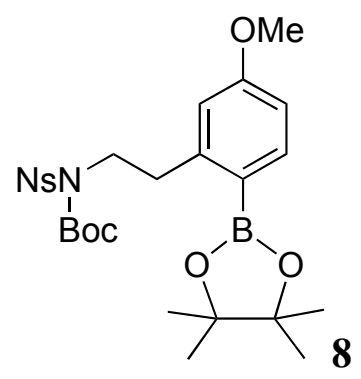

\section{$N$-Boc- $N$-nosyl-2-(5-methoxy-2-(4,4,5,5-tetramethyl-1,3,2-dioxaborolan-2-yl)phenyl)-}

ethanamine (8). To a solution of $1.69 \mathrm{~g}$ (3.0 mmol, 1.0 equiv) of 7, $13.5 \mathrm{mg}$ of $\mathrm{Pd}(\mathrm{OAc})_{2}(0.06$ mmol, $2 \mathrm{~mol} \%)$ and $48.5 \mathrm{mg}(0.09 \mathrm{mmol}, 3 \mathrm{~mol} \%)$ of DPEphos in $12 \mathrm{~mL}$ of 1,4-dioxane (degassed by 3 freeze $\&$ thaw cycles) was added at $\mathrm{rt} 1.05 \mathrm{~mL}$ (7.5 mmol, 2.5 equiv) of TEA and $673 \mu \mathrm{L}$ (4.5 mmol, 1.5 equiv) of pinacolborane. The reaction mixture was heated at $85{ }^{\circ} \mathrm{C}$ for $1 \mathrm{~h}$, then cooled to $\mathrm{rt}$, poured into a mixture of $50 \mathrm{~mL}$ of $1 / 2$ sat. aqueous $\mathrm{NH}_{4} \mathrm{Cl}$ solution and extracted with $\mathrm{Et}_{2} \mathrm{O}(3 \times 40 \mathrm{~mL})$. The combined organic phases were dried $\left(\mathrm{MgSO}_{4}\right)$ and concentrated. The residue was purified by chromatography on $\mathrm{SiO}_{2}$ with hexanes/EtOAc (9:1 -> $8: 2)$ to yield $1.57 \mathrm{~g}(86 \%)$ of 8 as a rubbery foam containing ca. $5 \%$ of deiodinated $7: \mathrm{R}_{\mathrm{f}} 0.24$ (hexanes/EtOAc, 7:3); GC $t_{\mathrm{R}} 24.51 \mathrm{~min}$ (92.9\%); FTIR (KBr) 3435, 3101, 2980, 2937, 2839, 1728,1602 , 1566, 1545, 1458, 1417, 1351, 1364, 1301, 1274, 1250, 1235, 1148, 1077, 1031, 1007, 964, 925, $858 \mathrm{~cm}^{-1} ;{ }^{1} \mathrm{H}$ NMR $\left(\mathrm{CDCl}_{3}\right) \delta 8.33-8.27(\mathrm{~m}, 1 \mathrm{H}), 7.77(\mathrm{~d}, J=8.3 \mathrm{~Hz}, 1 \mathrm{H})$, $7.72-7.68(\mathrm{~m}, 3 \mathrm{H}), 6.90(\mathrm{~d}, J=2.5 \mathrm{~Hz}, 1 \mathrm{H}), 6.77(\mathrm{dd}, J=8.3,2.5 \mathrm{~Hz}, 1 \mathrm{H}), 4.08(\mathrm{t}, J=6.7 \mathrm{~Hz}$, $2 \mathrm{H}), 3.83(\mathrm{~s}, 3 \mathrm{H}), 3.32(\mathrm{t}, J=6.7 \mathrm{~Hz}, 2 \mathrm{H}), 1.34(\mathrm{~s}, 12 \mathrm{H}), 1.18(\mathrm{~s}, 9 \mathrm{H}) ;{ }^{13} \mathrm{C} \mathrm{NMR}\left(\mathrm{CDCl}_{3}\right) \delta$ $162.0,150.6,147.8,147.6,138.3,134.1,133.8,133.6,131.8,124.3,115.9,112.1,84.4,83.5$, 
60.6, 55.3, 49.8, 36.8, 27.8, 25.0; HRMS (EI) $m / z$ calcd for $\mathrm{C}_{26} \mathrm{H}_{35} \mathrm{BN}_{2} \mathrm{O}_{9} \mathrm{~S} 561.2193$, found 561.2193.

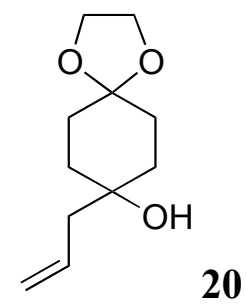

8-Allyl-1,4-dioxaspiro[4.5]decane-8-ol (20). To a stirred suspension of $4.95 \mathrm{~g}(30.4 \mathrm{mmol})$ of 1,4-cyclohexanedione monoethylene acetal (9), $5.95 \mathrm{~g}$ (91.1 mmol, 3.0 equiv) of $\mathrm{Zn}$ dust and $7.02 \mathrm{~g}$ (91.1 mmol, 3.0 equiv) of $\mathrm{NH}_{4} \mathrm{OAc}$ in $120 \mathrm{~mL}$ of dry THF at $\mathrm{rt}$ was added the first $0.5 \mathrm{~mL}$ of a total of $8.0 \mathrm{~mL}$ (91.1 mmol, 3.0 equiv) of allylbromide. After the reaction mixture got slightly warmer, the rest of the allylbromide was added within $5 \mathrm{~min}$, with occasional ice cooling. The mixture turned to a colorless suspension, and $100 \mathrm{~mL}$ of sat. $\mathrm{NaHCO}_{3}$ solution and $100 \mathrm{~mL}$ of EtOAc were added. The aqueous phase was extracted with EtOAc $(2 \times 100 \mathrm{~mL})$, and the combined organic phases washed with brine, dried $\left(\mathrm{MgSO}_{4}\right)$ and concentrated to give $6.23 \mathrm{~g}$ (quantitative yield) of $\mathbf{2 0}$ a colorless viscous oil: $\mathrm{R}_{\mathrm{f}} 0.20$ (hexanes/EtOAc, 7:3); GC $t_{\mathrm{R}} 8.69 \mathrm{~min}$ (98.9\%); FTIR (neat): 3473, 3074, 2932, 2885, 1716, 1639, 1477, 1437, 1370, 1337, 1263, 1166, 1097, 1036, 1003, 983, 972, 935, $892 \mathrm{~cm}^{-1} ;{ }^{1} \mathrm{H}$ NMR $\left(\mathrm{CDCl}_{3}\right) \delta 5.95-5.81(\mathrm{~m}, 1 \mathrm{H}), 5.19-5.09$ (m, 2 H), 3.95-3.94 (m, 4 H), 2.23 (d, $J=7.5$ Hz, 2 H), 1.95-1.85 (m, 2 H), 1.72-1.55 (m, $6 \mathrm{H}$ ), 1.37 (s, OH); ${ }^{13} \mathrm{C}$ NMR $\left(\mathrm{CDCl}_{3}\right) \delta$ 133.5, 119.4, 108.9, 70.0, 64.4, 64.3, 47.0, 34.8, 30.6; HRMS (EI) $m / z$ calcd for $\mathrm{C}_{11} \mathrm{H}_{18} \mathrm{O}_{3}$ 198.1256, found 198.1260.

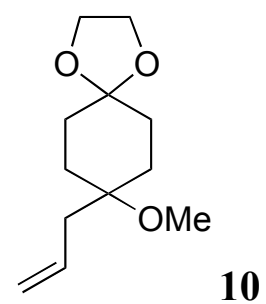

8-Allyl-8-methoxy-1,4-dioxaspiro[4.5]decane (10). To a solution of $1.01 \mathrm{~g}(5.0 \mathrm{mmol}, 1.0$ equiv) of 20 in $20 \mathrm{~mL}$ of dry THF was added under ice cooling $0.60 \mathrm{~g}$ ( $15.1 \mathrm{mmol}, 3.0$ equiv) of $\mathrm{NaH}(60 \%$ in mineral oil) and after stirring for $10 \mathrm{~min}$ at $\mathrm{rt} 0.95 \mathrm{~mL}$ (15.1 mmol, 3.0 equiv) of 
MeI. The reaction mixture was stirred at $\mathrm{rt}$ for $3 \mathrm{~h}$ (monitored by TLC), ${ }^{1}$ then cooled in an ice bath, quenched with sat. $\mathrm{NH}_{4} \mathrm{Cl}$ aqueous solution and extracted with $\mathrm{Et}_{2} \mathrm{O}(4 \times 25 \mathrm{~mL})$. The combined organic phases were washed with brine, dried $\left(\mathrm{MgSO}_{4}\right)$ and concentrated. The residue was purified by chromatography on $\mathrm{SiO}_{2}$ (hexanes/EtOAc, 9:1 -> 8:2) to yield $5.13 \mathrm{~g}(95 \%)$ of 10 as a colorless oil: $\mathrm{R}_{\mathrm{f}} 0.43$ (hexanes/EtOAc, 7:3); GC $t_{\mathrm{R}} 8.88 \mathrm{~min}$ (98.4\%); FTIR (neat) 3074, 2935, 2882, 2825, 1640, 1461, 1432, 1376, 1336, 1272, 1241, 1209, 1147, 1080, 1036, 1000, 975, 951, 935, 923, 888, $839 \mathrm{~cm}^{-1} ;{ }^{1} \mathrm{H}$ NMR $\left(\mathrm{CDCl}_{3}\right) \delta$ 5.86-5.72 (m, $\left.1 \mathrm{H}\right), 5.08-5.00(\mathrm{~m}, 2 \mathrm{H})$, 3.95-3.89 (m, 4 H), 3.17 (s, 3 H), 2.21 (d, $J=7.3$ Hz, 2 H), 1.83-1.73 (m, 4 H), 1.56-1.45 (m, 4 $\mathrm{H}) ;{ }^{13} \mathrm{C} \mathrm{NMR}\left(\mathrm{CDCl}_{3}\right) \delta 133.9,117.7,109.0,74.0,64.5,64.3,48.7,40.9,31.3,30.3$; HRMS (EI) $m / z$ calcd for $\mathrm{C}_{11} \mathrm{H}_{16} \mathrm{O}_{2} 180.1150(M-\mathrm{MeOH})$, found 180.1158 .

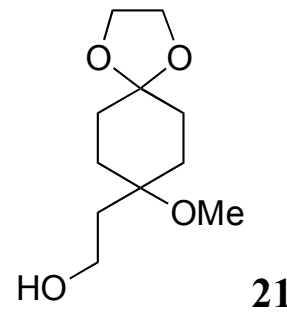

2-(8-Methoxy-1,4-dioxaspiro[4.5]dec-8-yl)ethanol (21). A solution of $1.04 \mathrm{~g}$ (4.82 mmol, 1.0 equiv) of 10 in $60 \mathrm{~mL}$ of $\mathrm{DCM} / \mathrm{MeOH}(9: 1)$ was treated with ozone gas at $-78{ }^{\circ} \mathrm{C}$ until a blue color persisted. After purging with $\mathrm{O}_{2}$ for several minutes, $0.74 \mathrm{~g}$ (19.3 mmol, 4.0 equiv) of $\mathrm{NaBH}_{4}$ was added and the mixture was stirred at $\mathrm{rt}$ for $4 \mathrm{~h}$. Then, $15 \mathrm{~mL}$ of sat. aqueous $\mathrm{NH}_{4} \mathrm{Cl}$ solution and $5 \mathrm{~mL}$ of water were slowly added and the reaction mixture was stirred for another 30 min. After phase separation, the aqueous phase was extracted with DCM $(3 \times 40 \mathrm{~mL})$. The combined organic phases were washed with brine, dried $\left(\mathrm{MgSO}_{4}\right)$ and concentrated. The residue was purified by chromatography on $\mathrm{SiO}_{2}$ (hexanes/EtOAc, 7:3 -> 0:1) to yield $1.01 \mathrm{~g}(96 \%)$ of 21 as a colorless viscous oil: $\mathrm{R}_{\mathrm{f}} 0.2$ (hexanes/EtOAc, 7:3); GC $t_{\mathrm{R}} 10.23 \mathrm{~min}$ (99.6\%); FTIR (neat) 3439, 2941, 2886, 2826, 1464, 1436, 1377, 1388, 1286, 1257, 1157, 1136, 1111, 1078, 1036, 946, $926 \mathrm{~cm}^{-1} ;{ }^{1} \mathrm{H} \mathrm{NMR}\left(\mathrm{CDCl}_{3}\right) \delta 3.91(\operatorname{app~t}, J=3.6 \mathrm{~Hz}, 4 \mathrm{H}), 3.74(\mathrm{t}, J=6.5 \mathrm{~Hz}, 2 \mathrm{H}), 3.18(\mathrm{~s}$, $3 \mathrm{H}), 2.49$ (s, $1 \mathrm{H}), 1.91-1.86(\mathrm{~m}, 2 \mathrm{H}), 1.77-1.70(\mathrm{~m}, 4 \mathrm{H}), 1.56-1.46(\mathrm{~m}, 4 \mathrm{H}) ;{ }^{13} \mathrm{C}$ NMR $\left(\mathrm{CDCl}_{3}\right) \delta 108.8,74.9,64.5,64.4,59.1,48.9,36.9,31.4,30.4$; HRMS (EI) $\mathrm{m} / z$ calcd for $\mathrm{C}_{10} \mathrm{H}_{16} \mathrm{O}_{3} 184.1099(M-\mathrm{MeOH})$, found 184.1097.

\footnotetext{
${ }^{1}$ In one case, the reaction was retarded and took $2 \mathrm{~d}$ to go to completion.
} 


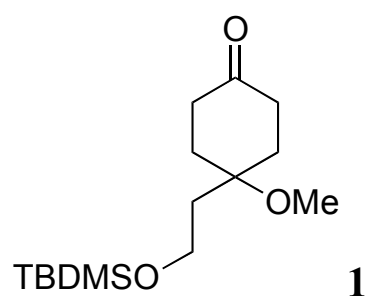

4-(2-(tert-Butyldimethylsilyloxy)ethyl)-4-methoxycyclohexanone (11). A solution of $4.14 \mathrm{~g}$ (19.2 mmol, 1.0 equiv) of 21 and $0.98 \mathrm{~g}$ (3.8 mmol, 0.2 equiv) of PPTS in $72 \mathrm{~mL}$ of acetone/water (1:1) was heated at reflux for $12 \mathrm{~h}$. One half of the solvent was distilled off and the aqueous phase was extracted with EtOAc $(10 \times 50 \mathrm{~mL})$. The combined organic phases were concentrated and the residue was purified by chromatography on $\mathrm{SiO}_{2}$ (hexanes/EtOAc, 1:1 -> $2: 8)$ to yield $2.29 \mathrm{~g}(68 \%)$ of the corresponding hydroxyketone: $\mathrm{R}_{\mathrm{f}} 0.24$ (hexanes/EtOAc, 3:7). To a solution of $2.21 \mathrm{~g}$ (12.5 mmol, 1.0 equiv) of the hydroxyketone and $1.29 \mathrm{~g}$ (18.8 mmol, 1.5 equiv) of imidazole in $20 \mathrm{~mL}$ dry of DMF was added a solution of $2.27 \mathrm{~g}$ (15.1 mmol, 1.2 equiv) of tert-butyldimethylchlorosilane in $6 \mathrm{~mL}$ of DMF. The reaction mixture was stirred at $\mathrm{rt}$ for 15 h, poured into a mixture of $50 \mathrm{~mL}$ of sat. $\mathrm{NH}_{4} \mathrm{Cl}$ solution and $100 \mathrm{~mL} \mathrm{H}_{2} \mathrm{O}$ and extracted with $\mathrm{Et}_{2} \mathrm{O}(5 \times 50 \mathrm{~mL})$. the combined organic phases were dried $\left(\mathrm{MgSO}_{4}\right)$ and concentrated. The residue was purified by chromatography on $\mathrm{SiO}_{2}$ (hexanes/EtOAc, 9.5:0.5 -> 8:2) to yield $3.12 \mathrm{~g}$ of 11 (58\%, 2 steps) as a colorless liquid: $\mathrm{R}_{\mathrm{f}} 0.47$ (hexanes/EtOAc, 7:3); GC $t_{\mathrm{R}} 11.40 \mathrm{~min}$ (98.5\%); FTIR (neat): 2952, 2886, 2857, 2826, 1718, 1472, 1464, 1414, 1389, 1361, 1254, 1138, 1126, 1078, 1036, 1007, 890, 837, 776, 711, 662, $507 \mathrm{~cm}^{-1} ;{ }^{1} \mathrm{H} \mathrm{NMR}\left(\mathrm{CDCl}_{3}\right) \delta 3.70(\mathrm{t}, J=7.2$ $\mathrm{Hz}, 2 \mathrm{H}), 3.24(\mathrm{~s}, 3 \mathrm{H}), 2.60-2.48$ (m, $2 \mathrm{H}), 2.20-2.10$ (m, $4 \mathrm{H}), 1.79$ (t, J= 7.2 Hz, $2 \mathrm{H}), 1.69$ $(\mathrm{dt}, J=13.5,5.2 \mathrm{~Hz}, 2 \mathrm{H}), 0.86(\mathrm{~s}, 9 \mathrm{H}), 0.03(\mathrm{~s}, 6 \mathrm{H}) ;{ }^{13} \mathrm{C} \mathrm{NMR}\left(\mathrm{CDCl}_{3}\right) \delta$ 212.0, 73.4, 58.7, 49.1, 38.6, 36.9, 34.0, 26.1, 18.4, -5.2; HRMS (EI) $m / z$ calcd for $\mathrm{C}_{14} \mathrm{H}_{27} \mathrm{O}_{3} \mathrm{Si}(M-\mathrm{Me}) 271.1729$, found 271.1727 .

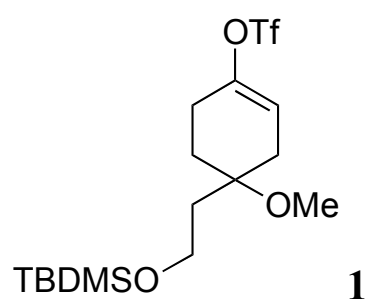


4-(2-(tert-Butyldimethylsilyloxy)ethyl)-4-methoxycyclohex-1-enyltrifluoromethanesulfonate (12). To a solution of $399 \mathrm{mg}$ (1.38 mmol, 1.0 equiv) of 11 and $602 \mathrm{mg}$ (1.65 mmol, 1.2 equiv) of $N$-phenyl-bis(trifluoromethanesulfonimide) in $8.8 \mathrm{~mL}$ of dry $\mathrm{THF}$ at $-78^{\circ} \mathrm{C}$ was added slowly a solution of $318 \mathrm{mg}$ (1.51 mmol, 1.1 equiv) of KHMDS in $5 \mathrm{~mL}$ of THF. The reaction mixture was allowed to warm to rt within $4 \mathrm{~h}$, quenched with sat. $\mathrm{NH}_{4} \mathrm{Cl}$ solution and extracted with $\mathrm{Et}_{2} \mathrm{O}$. The organic phase was washed with brine, dried $\left(\mathrm{MgSO}_{4}\right)$ and concentrated. The residue was purified by chromatography on $\mathrm{SiO}_{2}$ (hexanes/EtOAc, 95:5) to yield $563 \mathrm{mg}$ of 12 (98\%) as a colorless oil: $\mathrm{R}_{\mathrm{f}} 0.67$ (hexanes/EtOAc, 7:3); GC $t_{\mathrm{R}} 11.80 \mathrm{~min}$ (100\%); FTIR (neat) 2933, 2887, 2858, 2828, 1696, 1472, 1464, 1418, 1374, 1362, 1248, 1210, 1145, 1090, 1035, 988, 966, 858 $\mathrm{cm}^{-1} ;{ }^{1} \mathrm{H}$ NMR $\left(\mathrm{CDCl}_{3}\right) \delta 5.62-5.59(\mathrm{~m}, 1 \mathrm{H}), 3.71(\mathrm{t}, J=6.8 \mathrm{~Hz}, 2 \mathrm{H}), 3.17(\mathrm{~s}, 3 \mathrm{H}), 2.51-2.43$ (m, $1 \mathrm{H}), 2.39-2.19(\mathrm{~m}, 3 \mathrm{H}), 2.03-1.95(\mathrm{~m}, 1 \mathrm{H}), 1.89-1.66(\mathrm{~m}, 3 \mathrm{H}), 0.88(\mathrm{~s}, 9 \mathrm{H}), 0.04(\mathrm{~s}, 6$ $\mathrm{H}) ;{ }^{13} \mathrm{C} \mathrm{NMR}\left(\mathrm{CDCl}_{3}\right) \delta 148.8,118.7$ (q, $\left.J=318 \mathrm{~Hz}\right), 115.2,72.7,58.6,49.2,37.9,33.6,30.7$, 26.1, 25.0, 18.4, -5.2; HRMS (EI) $\mathrm{m} / z$ calcd for $\mathrm{C}_{16} \mathrm{H}_{30} \mathrm{~F}_{3} \mathrm{O}_{5} \mathrm{SSi} 419.1535(M+\mathrm{H})$, found 419.1552 .

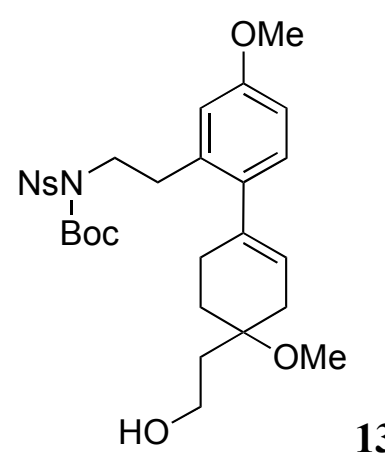

$N$-Boc- $N$-nosyl-2-(4-(2-(2-aminoethyl)-4-methoxyphenyl)-1-methoxycyclohex-3-enyl)ethanol (13). To a solution of $1.47 \mathrm{~g}$ (2.43 mmol, 1.0 equiv, 93\% pure by GC analysis) of boronic ester 8 and $1.02 \mathrm{~g}$ (2.43 mmol, 1.0 equiv) of vinyl triflate 12 in $12 \mathrm{~mL}$ of DMSO (degassed by 3 freeze \& thaw cycles) was added $1.58 \mathrm{~g}$ (4.86 mmol, 2 equiv) of $\mathrm{Cs}_{2} \mathrm{CO}_{3}$ and $140 \mathrm{mg}(5 \mathrm{~mol} \%)$ of $\mathrm{Pd}\left(\mathrm{PPh}_{3}\right)_{4}$. The mixture was heated under an $\mathrm{N}_{2}$-atmosphere at $81{ }^{\circ} \mathrm{C}$ for $2 \mathrm{~h}$, cooled to rt, poured into a mixture of $25 \mathrm{~mL}$ of sat. $\mathrm{NH}_{4} \mathrm{Cl}$ solution and $100 \mathrm{~mL}$ of $\mathrm{H}_{2} \mathrm{O}$ and extracted with $\mathrm{Et}_{2} \mathrm{O}$ $(3 \times 50 \mathrm{~mL})$. The combined organic phases were dried $\left(\mathrm{MgSO}_{4}\right)$ and concentrated. The residue was purified by chromatography on $\mathrm{SiO}_{2}$ (hexanes/EtOAc, 9:1 -> 8.5:1.5). The crude TBDMS-ether (1.43 g, $\mathrm{R}_{\mathrm{f}}$ 0.32, hexanes/EtOAc, 7:3) containing deiodinated 7 was dissolved in $25 \mathrm{~mL}$ of THF, and $7.3 \mathrm{~mL}$ (7.3 mmol, 3 equiv) of TBAF solution (1 M in THF) was added at $\mathrm{rt}$ After stirring for 
$3 \mathrm{~h}$ (monitored by TLC), the reaction mixture was poured into $40 \mathrm{~mL}$ of $50 \%$ sat. $\mathrm{NH}_{4} \mathrm{Cl}$ solution and extracted with $\mathrm{Et}_{2} \mathrm{O}(3 \times 50 \mathrm{~mL})$. The combined organic phases were dried $\left(\mathrm{MgSO}_{4}\right)$ and concentrated. The residue was purified by chromatography on $\mathrm{SiO}_{2}$ (hexanes/EtOAc, 1:1 -> 4:6) to yield $946 \mathrm{mg}\left(66 \%, 2\right.$ steps) of 13 as an orange brown resin: $\mathrm{R}_{\mathrm{f}} 0.25$ (hexanes/EtOAc, 3:7). FTIR (KBr) 3434, 2970, 2937, 2836, 1735, 1607, 1571, 1544, 1501, 1458, 1369, 1293, 1259, 1237, 1153, 1123, 1072, 971, 852, $816 \mathrm{~cm}^{-1} ;{ }^{1} \mathrm{H}$ NMR $\left(\mathrm{CDCl}_{3}\right) \delta$ 8.30-8.27 (m, $\left.1 \mathrm{H}\right), 7.77-7.69$ $(\mathrm{m}, 3 \mathrm{H}), 7.00(\mathrm{~d}, J=8.4 \mathrm{~Hz}, 1 \mathrm{H}), 6.82(\mathrm{~d}, J=2.6 \mathrm{~Hz}, 1 \mathrm{H}), 6.73(\mathrm{dd}, J=8.4,2.7 \mathrm{~Hz}, 1 \mathrm{H}), 5.49$ (bs, $1 \mathrm{H}), 3.92-3.82(\mathrm{~m}, 4 \mathrm{H}), 3.79(\mathrm{~s}, 3 \mathrm{H}), 3.28$ (s, $3 \mathrm{H}), 2.99$ (t, J= 7.9 Hz, 2 H), 2.50-2.21 (m, $4 \mathrm{H}), 2.09-1.90(\mathrm{~m}, 1 \mathrm{H}), 1.88-1.80(\mathrm{~m}, 3 \mathrm{H}), 1.34(\mathrm{~s}, 9 \mathrm{H}) ;{ }^{13} \mathrm{C} \mathrm{NMR}\left(\mathrm{CDCl}_{3}\right) \delta$ 158.6, 150.4, $147.8,136.9,136.7,136.6,134.3,133.7,133.3,131.9,129.9,124.5,124.1,115.1,112.4,85.2$, 75.9, 59.4, 55.4, 49.4, 49.0, 36.3, 34.5, 34.4, 30.3, 29.8, 28.0; HRMS (EI) $\mathrm{m} / z$ calcd for $\mathrm{C}_{28} \mathrm{H}_{34} \mathrm{~N}_{2} \mathrm{O}_{8} \mathrm{~S} 558.2036(M-\mathrm{MeOH})$, found 558.2044.

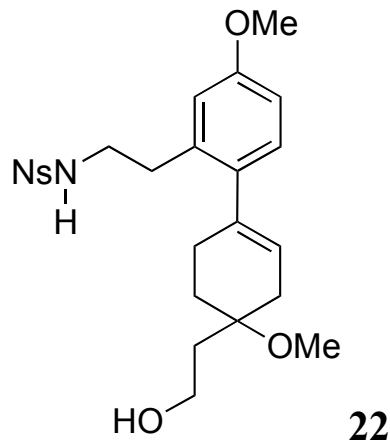

$\mathrm{N}$-Nosyl-2-(4-(2-(2-aminoethyl)-4-methoxyphenyl)-1-methoxycyclohex-3-enyl)ethanol (22). $946 \mathrm{mg}(1.60 \mathrm{mmol})$ of 13 was heated neat for $20 \mathrm{~min}$ at $165^{\circ} \mathrm{C}$ under a $\mathrm{N}_{2}$ atmosphere. After cooling to rt, the crude product was dissolved in $2 \mathrm{~mL}$ of DCM and purified by chromatography on $\mathrm{SiO}_{2}$ (hexanes/EtOAc, 1:1 -> 2:8) to yield $705 \mathrm{mg}(90 \%)$ of 22 as a viscous oil that partly solidified after a few hours: $\mathrm{R}_{\mathrm{f}} 0.19$ (hexanes/EtOAc, 7:3); Mp 121.9-123.6 ${ }^{\circ} \mathrm{C}$; FTIR $(\mathrm{KBr})$ $3491,3318,2941,2836,1607,1572,1542,1498,1443,1421,1365,1337,1291,1259,1241$, 1165, 1125, 1079, 1023, 854, $815 \mathrm{~cm}^{-1} ;{ }^{1} \mathrm{H}$ NMR $\left(\mathrm{CDCl}_{3}\right) \delta 8.07(\mathrm{dd}, J=5.9,3.4 \mathrm{~Hz}, 1 \mathrm{H}), 7.83$ (dd, $J=6.0,3.3 \mathrm{~Hz}, 1 \mathrm{H}), 7.74-7.68(\mathrm{~m}, 2 \mathrm{H}), 6.97$ (d, $J=8.4 \mathrm{~Hz}, 1 \mathrm{H}), 6.69$ (dd, $J=8.4,2.6 \mathrm{~Hz}$, $1 \mathrm{H}), 6.59(\mathrm{~d}, J=2.6 \mathrm{~Hz}, 1 \mathrm{H}), 5.43(\mathrm{t}, J=5.9 \mathrm{~Hz}, 1 \mathrm{H}), 5.38(\mathrm{bs}, 1 \mathrm{H}), 3.84$ (t, $6.2 \mathrm{~Hz}, 2 \mathrm{H}), 3.74$ (s, 3 H), 3.34-3.21 (m, 2 H), 3.27 (s, 3 H), 2.83 (t, J= 7.3 Hz, 2 H), 2.55 (bs, 1 H), 2.42-2.07 (m, $4 \mathrm{H}), 2.03-1.68(\mathrm{~m}, 4 \mathrm{H}) ;{ }^{13} \mathrm{C}$ NMR $\left(\mathrm{CDCl}_{3}\right) \delta$ 158.6, 148.1, 137.3, 136.4, 136.1, 133.9, 133.6, 
132.9, 131.0, 130.1, 125.4, 123.7, 115.1, 112.1, 75.0, 59.0, 55.4, 49.0, 44.9, 36.6, 34.7, 33.9, 30.5, 29.3; HRMS (ESI) $m / z$ calcd for $\mathrm{C}_{24} \mathrm{H}_{30} \mathrm{~N}_{2} \mathrm{O}_{7} \mathrm{NaS} 513.1671(M+\mathrm{Na}$ ), found 513.1686.

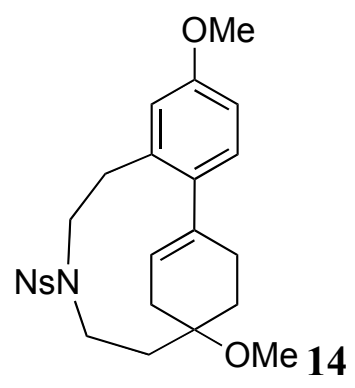

N-Nosyl-4-aza-4'-methoxybenzo[2',1'-g]bicyclo[7.2.2]tridec-9(10)-ene (14). To a solution of $705 \mathrm{mg}$ (1.44 mmol, 1.0 equiv) of 22 and $1.14 \mathrm{~g}$ (4.31 mmol, 3.0 equiv) of triphenylphosphane in $52 \mathrm{~mL}$ of dry toluene and $18 \mathrm{~mL}$ of dry THF was added at rt dropwise a solution of $1.96 \mathrm{~mL}$ (4.31 mmol, 3.0 equiv) of 40\% diethyl azodicarboxylate (DEAD) in toluene. After stirring for 12 h, $0.5 \mathrm{~mL} \mathrm{H}_{2} \mathrm{O}$ was added and after another $30 \mathrm{~min}$ the mixture was concentrated. The residue was purified by chromatography on $\mathrm{SiO}_{2}$ (hexanes/EtOAc, 7:3 -> 4:6). The product was further crystallized from $\mathrm{Et}_{2} \mathrm{O} /$ hexanes to yield $389 \mathrm{mg}(57 \%)$ of 14 as a colorless solid: $\mathrm{R}_{\mathrm{f}} 0.44$ (hexanes/EtOAc, 3:7); Mp 179.6-180.6 ${ }^{\circ} \mathrm{C}$ (Et $2 \mathrm{O} /$ hexanes); FTIR (KBr) 3436, 2941, 1605, 1544, $1498,1465,1373,1349,1293,1255,1164,1140,1127,1075,1057,1041,973,900,852,814$ $\mathrm{cm}^{-1} ;{ }^{1} \mathrm{H}$ NMR $\left(\mathrm{CDCl}_{3}\right) \delta$ 8.05-8.00 (m, $\left.1 \mathrm{H}\right), 7.70-7.67(\mathrm{~m}, 2 \mathrm{H}), 7.65-7.60(\mathrm{~m}, 1 \mathrm{H}), 7.05(\mathrm{~d}, J$ $=8.2 \mathrm{~Hz}, 1 \mathrm{H}), 6.77-6.72(\mathrm{~m}, 2 \mathrm{H}), 5.62(\mathrm{~d}, J=6.3 \mathrm{~Hz}, 1 \mathrm{H}), 4.02-3.85(\mathrm{~m}, 1 \mathrm{H}), 3.78(\mathrm{~s}, 3 \mathrm{H})$, 3.71-3.59 (m, 1H), 3.33-3.26 (m, 1H), 3.23 (s, 3H), 3.11 (dd, J=15.0, 7.0 Hz, 1H), 3.02-2.94 (m, $1 \mathrm{H}), 2.72-2.58(\mathrm{~m}, 2 \mathrm{H}), 2.50(\mathrm{dd}, J=16.5,7.1 \mathrm{~Hz}, 1 \mathrm{H}), 2.41-2.29(\mathrm{~m}, 1 \mathrm{H}), 2.23-2.09$ (m, $2 \mathrm{H}), 1.90-1.85(\mathrm{~m}, 2 \mathrm{H}), 1.69(\mathrm{dd}, J=16.8,6.1 \mathrm{~Hz}, 1 \mathrm{H}) ;{ }^{13} \mathrm{C} \mathrm{NMR}\left(\mathrm{CDCl}_{3}\right) \delta 158.6,148.2$, $138.3,137.9,134.8,133.7,133.6,131.9,131.0,129.4,124.7,124.4,116.9,112.2,76.8,55.4$, 50.0, 46.4, 43.6, 35.7, 32.8, 32.5, 31.9, 31.7; HRMS (EI) $m / z$ calcd for $\mathrm{C}_{24} \mathrm{H}_{28} \mathrm{~N}_{2} \mathrm{O}_{6} \mathrm{~S} 472.1668$, found 472.1691 .

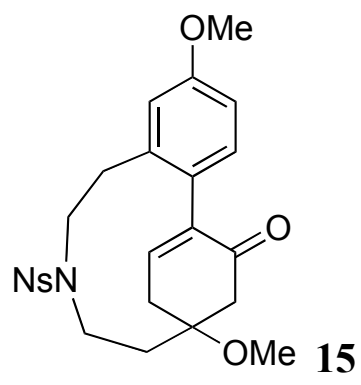


N-Nosyl-4-aza-4'-methoxybenzo[2',1'-g]bicyclo[7.2.2]tridec-9(13)-ene-10-one (15). To a cold (ice bath) solution of $389 \mathrm{mg}(0.82 \mathrm{mmol}, 1.0$ equiv) of $14 \mathrm{in} 25 \mathrm{~mL}$ of DCM was added $244 \mathrm{mg}$ ( $0.99 \mathrm{mmol}, 1.2$ equiv) of $70-75 \% \mathrm{mCPBA}$. After the addition, the ice bath was removed and the mixture was stirred at $\mathrm{rt}$ for $17 \mathrm{~h}$. Most of the solvent was distilled off at $\mathrm{r} . \mathrm{t}$ under reduced pressure, and the residue purified by chromatography on $\mathrm{SiO}_{2}$ (hexanes/EtOAc, 6:4 -> 4:6) to yield $390 \mathrm{mg}(97 \%)$ of the corresponding epoxide as a colorless solid: $\mathrm{R}_{\mathrm{f}} 0.37$ (hexanes/EtOAc, 3:7). To a solution of $390 \mathrm{mg}(0.80 \mathrm{mmol})$ of the epoxide in $25 \mathrm{~mL}$ of dry $\mathrm{CHCl}_{3}$ was added 0.70 $\mathrm{mg}(8 \mu \mathrm{mol}, 1 \mathrm{~mol} \%)$ of tetrafluoroboric acid $(260 \mu \mathrm{L}$ of a solution of $58 \mathrm{mg}$ of $48 \%$ aqueous $\mathrm{HBF}_{4}$ in $10 \mathrm{~mL}$ of $\mathrm{CHCl}_{3}$, dried over $200 \mathrm{mg} \mathrm{MgSO}$ and filtered). The mixture was stirred at $\mathrm{rt}$ for $22 \mathrm{~h}$ or until the SM was consumed (TLC), then the solution was concentrated to give $393 \mathrm{mg}$ of the allylic alcohol as a colorless solid: $\mathrm{R}_{\mathrm{f}} 0.17$ (hexanes/EtOAc, 3:7); $\mathrm{Mp} 185-187{ }^{\circ} \mathrm{C}\left(\mathrm{Et}_{2} \mathrm{O}\right)$; HRMS (EI) $m / z$ calcd for $\mathrm{C}_{24} \mathrm{H}_{26} \mathrm{~N}_{2} \mathrm{O}_{6} \mathrm{~S} 470.1512\left(M-\mathrm{H}_{2} \mathrm{O}\right)$, found 470.1525.

To a suspension of $393 \mathrm{mg}(0.80 \mathrm{mmol}, 1.0$ equiv) of the allylic alcohol in $30 \mathrm{~mL}$ of DCM was added $420 \mathrm{mg}$ (1.12 mmol, 1.4 equiv) of Dess-Martin periodinane. The reaction mixture was stirred at $\mathrm{rt}$ for $1 \mathrm{~h}$, and treated with $30 \mathrm{~mL}$ of $\mathrm{Et}_{2} \mathrm{O}, 30 \mathrm{~mL}$ of sat. aqueous $\mathrm{NaHCO}_{3}$ solution and $30 \mathrm{~mL}$ of sat. aqueous $\mathrm{Na}_{2} \mathrm{~S}_{2} \mathrm{O}_{3}$ solution. The biphasic mixture was stirred vigorously for $30 \mathrm{~min}$. The aqueous phase was extracted with $\mathrm{Et}_{2} \mathrm{O}(3 \times 25 \mathrm{~mL})$, and the combined organic phases were dried $\left(\mathrm{MgSO}_{4}\right)$ and concentrated. Chromatography on $\mathrm{SiO}_{2}$ (hexanes/EtOAc, 1:1 -> 3:7) yielded $253 \mathrm{mg}$ (65\%, 2 steps) of $\mathbf{1 5}$ as a colorless solid: $\mathrm{R}_{\mathrm{f}} 0.21$ (hexanes/EtOAc, 3:7); Mp 190.2-191.4 ${ }^{\circ} \mathrm{C}$; FTIR (KBr) 3435, 3097, 2941, 2909, 2835, 1671, 1607, 1544, 1505, 1460, 1375, 1348, 1298 , 1267, 1241, 1213, 1170, 1123, 1077, 1042, 966, $852 \mathrm{~cm}^{-1} ;{ }^{1} \mathrm{H}$ NMR (DMSO-d 6 , $354 \mathrm{~K}$ ) $\delta 8.02-$ 7.99 (m, $1 \mathrm{H}), 7.96-7.91$ (m, 2 H), 7.90-7.85 (m, $1 \mathrm{H}), 7.06-7.03$ (m, $1 \mathrm{H}), 7.03$ (dd, $J=7.9,0.7$ Hz, 1 H), 6.86-6.82 (m, 1 H), 6.82 (s, 1 H), 3.81 (s, 3 H), 3.38-3.23 (m, 2 H), 3.26 (s, 3 H), 3.223.15 (m, 2 H), 3.12-2.98 (m, 1 H), 2.81-2.78 (m, 3 H), 2.78-2.69 (m, 2 H), 2.13-2.08 (m, 2 H); ${ }^{13} \mathrm{C}$ NMR (DMSO-d 6 , 354 K) $\delta 196.2,159.3,148.9,146.9,140.5,140.2,135.2,132.6,131.6$, $131.1,129.7,129.2,124.7,116.5,112.2,78.0,55.7,51.6,49.6,49.3,46.9,36.9,35.5,33.1$; HRMS (ESI) $m / z$ calcd for $\mathrm{C}_{24} \mathrm{H}_{26} \mathrm{~N}_{2} \mathrm{O}_{7} \mathrm{NaS} 509.1358(M+\mathrm{Na})$, found 509.1334. 


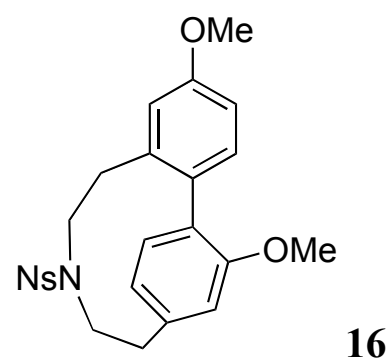

$\mathrm{N}$-Nosyl-1 ${ }^{2}, 2^{4}$-dimethoxy-5-aza-1(1,4),2(1,2)-dibenzenacycloheptaphane (16) To $30 \mathrm{mg}$ $(0.062 \mathrm{mmol})$ of $15 \mathrm{in} \mathrm{a} 10 \mathrm{~mL}$ pressure tube was added $1.25 \mathrm{~mL}$ of 2,2,2-trifluoroethanol and $1.25 \mathrm{~mL}$ of DIPEA. The flask was filled with Ar, closed and heated for $1 \mathrm{~h}$ at $170{ }^{\circ} \mathrm{C}$. The mixture was concentrated, dissolved in $2.5 \mathrm{~mL}$ of acetone, treated with $43 \mathrm{mg}(0.31 \mathrm{mmol}, 5$ equiv) of $\mathrm{K}_{2} \mathrm{CO}_{3}$ and $18 \mu \mathrm{L}(0.19 \mathrm{mmol}, 3$ equiv) of dimethylsulfate and heated at reflux for $7 \mathrm{~h}$. The reaction mixture was concentrated and directly purified on $\mathrm{SiO}_{2}$ (hexanes/EtOAc, 7:3) to give $25.9 \mathrm{mg}(90 \%)$ of 16 as a colorless solid: $\mathrm{R}_{\mathrm{f}} 0.54$ (hexanes/EtOAc 3:7); FTIR (KBr) 3435, 3000, 2958, 2936, 2862, 2835, 1592, 1570, 1545, 1506, 1462, 1403, 1374, 1354, 1329, 1281, 1246, 1166, 1126, 1084, 1034, 985, 916, 877, 852, 830, $802 \mathrm{~cm}^{-1} ;{ }^{1} \mathrm{H}-\mathrm{NMR}\left(\mathrm{CDCl}_{3}\right) \delta 7.89-7.87$ (m, 1 H), 7.72-7.64 (m, 2 H), 7.58-7.55 (m, 1 H), 7.49 (d, J=8.2 Hz, 1 H), 7.04 (d, J= 7.9 Hz, 1 H), 6.98-6.94 (m, 2 H), 6.87 (dd, $J=8.2,2.7 \mathrm{~Hz}, 1 \mathrm{H}), 6.68$ (d, $J=2.6 \mathrm{~Hz}, 1 \mathrm{H}), 3.92-3.69$ (m, 1 $\mathrm{H}), 3.85(\mathrm{~s}, 3 \mathrm{H}), 3.78(\mathrm{~s}, 3 \mathrm{H}), 2.98-2.63(\mathrm{~m}, 5 \mathrm{H}), 2.24-2.14(\mathrm{~m}, 1 \mathrm{H}), 0.83-0.69(\mathrm{~m}, 1 \mathrm{H}) ;{ }^{13} \mathrm{C}-$ NMR $\left(\mathrm{CDCl}_{3}\right) \delta 159.5,158.9,149.0,143.4,140.5,134.1,133.8,133.3,131.8,131.5,131.0$, 127.7, 127.2, 124.3, 122.4, 118.5, 117.8, 112.2, 59.8, 56.2, 55.6, 50.7, 39.2, 38.7; HRMS (EI) $\mathrm{m} / z$ calcd for $\mathrm{C}_{24} \mathrm{H}_{24} \mathrm{~N}_{2} \mathrm{O}_{6} \mathrm{~S} 468.1355$, found 468.1371 .

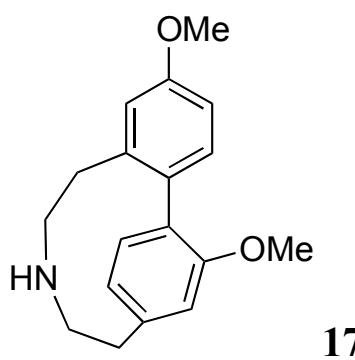

$\mathbf{1}^{\mathbf{2}}, \mathbf{2}^{4}$-Dimethoxy-5-aza-1(1,4),2(1,2)-dibenzenacycloheptaphane (17). To a solution of $25.9 \mathrm{mg}$ (0.055 mmol, 1.0 equiv) of $\mathbf{1 6}$ in $1.5 \mathrm{~mL}$ of DMF was added $30.6 \mathrm{mg}(0.221 \mathrm{mmol}, 4.0$ equiv) of $\mathrm{K}_{2} \mathrm{CO}_{3}$ and $17 \mu \mathrm{L}$ of $\mathrm{PhSH}(0.166 \mathrm{mmol}, 3.0$ equiv). The resulting suspension was stirred at $\mathrm{rt}$ for $2.5 \mathrm{~h}$, quenched with $15 \mathrm{~mL}$ of $2 \mathrm{~N}$ aqueous $\mathrm{NaOH}$ solution and extracted with $\mathrm{Et}_{2} \mathrm{O}(4 \times 15 \mathrm{~mL})$. The combined organic phases were dried $\left(\mathrm{MgSO}_{4}\right)$ and concentrated. Chromatography on $\mathrm{SiO}_{2}$ 
$\left(\mathrm{DCM} / \mathrm{MeOH}, 95: 5+1 \% \mathrm{v} / \mathrm{v}\right.$ TEA) followed by a chromatography on $\mathrm{C} 18 \mathrm{SiO}_{2}\left(\mathrm{ACN} / \mathrm{H}_{2} \mathrm{O} 1: 1\right.$ $+0.2 \% \mathrm{v} / \mathrm{v}$ conc. $\mathrm{NH}_{4} \mathrm{OH}$ solution-> pure $\left.\mathrm{ACN}\right)$ resulted in $9.5 \mathrm{mg}(61 \%)$ of 17 as a colorless resin: $\mathrm{R}_{\mathrm{f}} 0.25(\mathrm{DCM} / \mathrm{MeOH}, 95: 5$ + 1\% v/v TEA); FTIR (neat) 2997, 2930, 2833, 1605, 1589, 1568, 1503, 1473, 1400, 1397, 1274, 1256, 1242, 1161, 1124, 1110, 1083, 1036, 1001, 913, 868, $822 \mathrm{~cm}^{-1} ;{ }^{1} \mathrm{H}-\mathrm{NMR}\left(\mathrm{CDCl}_{3}\right) \delta 7.49(\mathrm{~d}, J=8.1 \mathrm{~Hz}, 1 \mathrm{H}), 7.05(\mathrm{~d}, J=7.9 \mathrm{~Hz}, 1 \mathrm{H}), 6.99(\mathrm{~d}, J=8.1$ $\mathrm{Hz}, 1 \mathrm{H}), 6.87$ (s, $1 \mathrm{H}), 6.84(\mathrm{dd}, J=8.3,2.7 \mathrm{~Hz}, 1 \mathrm{H}), 6.63$ (d, J=2.4 Hz, $1 \mathrm{H}), 3.88-3.71$ (m, 1 H), 3.81 (bs, $3 \mathrm{H}), 3.78$ (s, $3 \mathrm{H}), 3.15-3.11(\mathrm{~m}, 1 \mathrm{H}), 2.87$ (dd, J=11.7, 3.6 Hz, $1 \mathrm{H}), 2.64-2.50$ (m, $1 \mathrm{H}), 2.44-2.38(\mathrm{~m}, 1 \mathrm{H}), 2.29-2.15(\mathrm{~m}, 2 \mathrm{H}), 2.06-1.96(\mathrm{~m}, 1 \mathrm{H}), 0.09-0.16(\mathrm{~m}, 1 \mathrm{H}) ;{ }^{13} \mathrm{C}-$ NMR $\left(\mathrm{CDCl}_{3}\right) \delta 159.1,158.6,144.3,141.7,134.2,133.2,127.9,127.2,123.0,117.9,117.8$, 111.4, 56.4, 55.4, 53.6, 47.2, 39.6, 39.3; HRMS (EI) $m / z$ calcd for $\mathrm{C}_{18} \mathrm{H}_{21} \mathrm{NO}_{2} 283.1572$, found 283.1569 . 


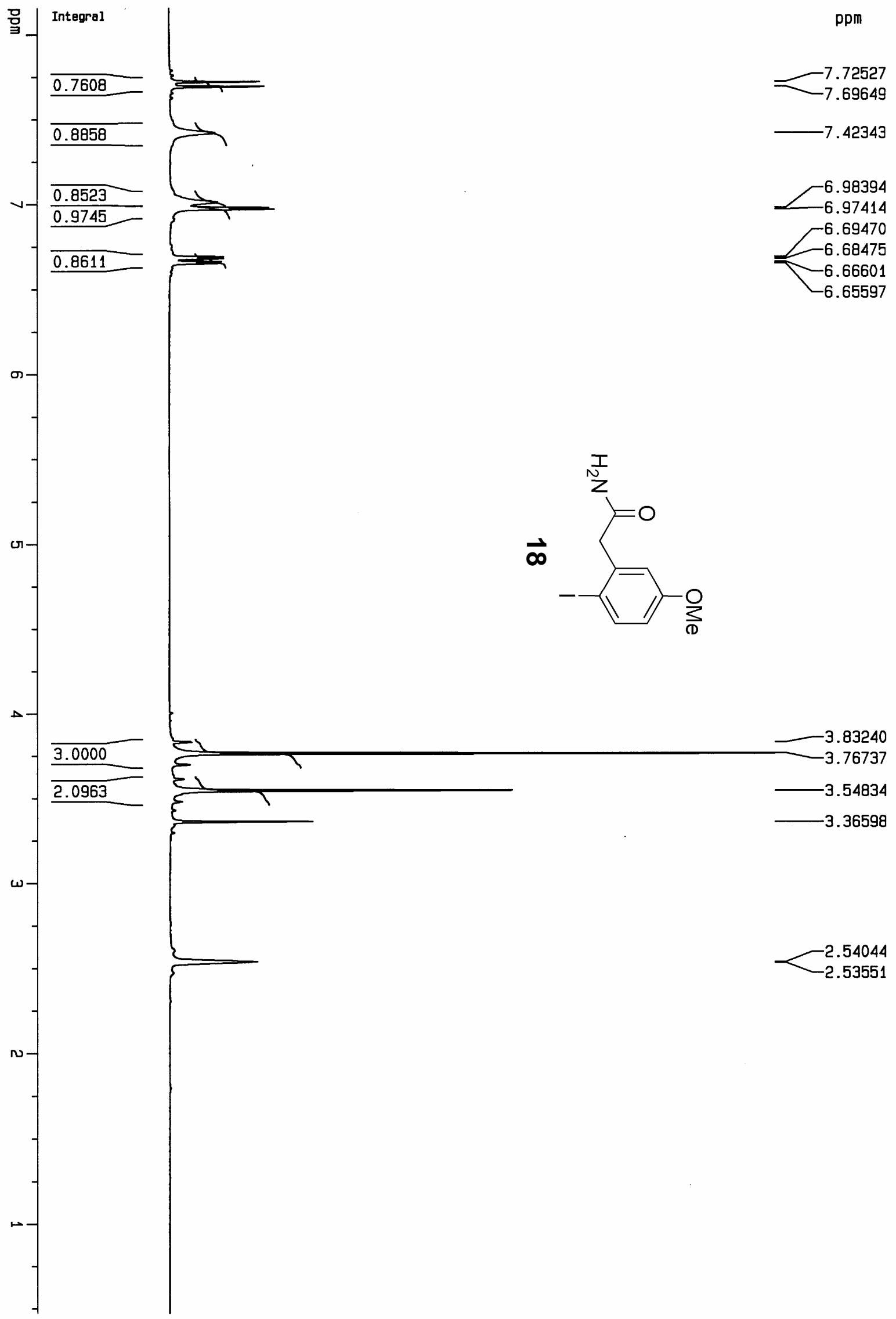




\section{믘}
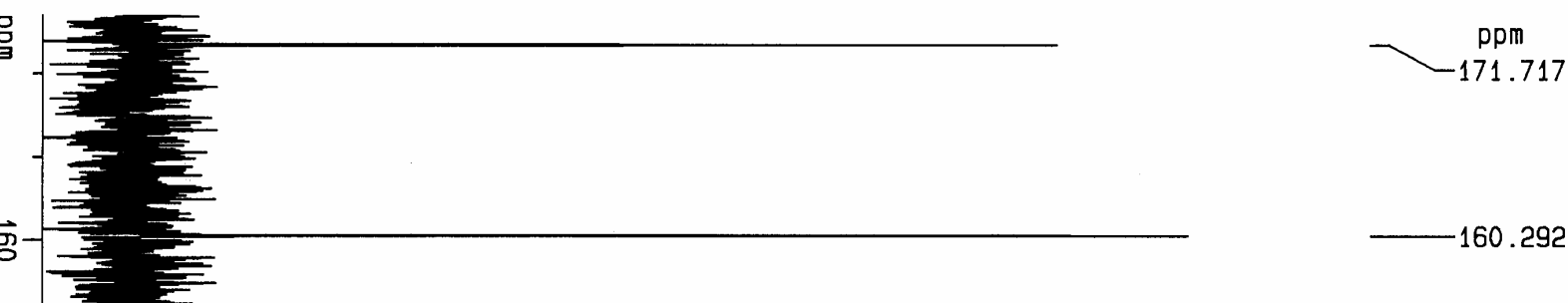

$-160.292$

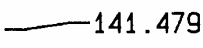

客

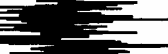

140.117

뭉

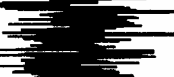

$=\equiv$

$\equiv$

$-118.172$

115.351

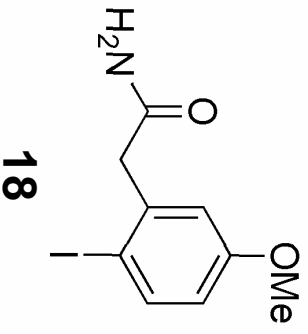

91.079

吅

8

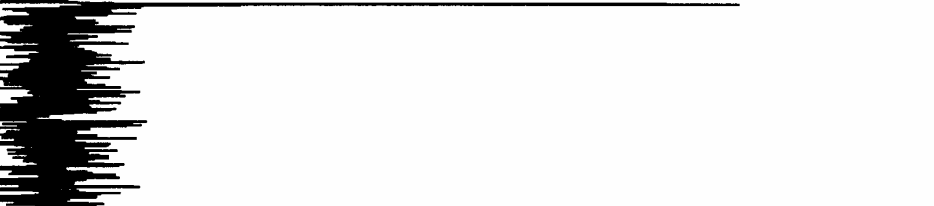

$=$ 


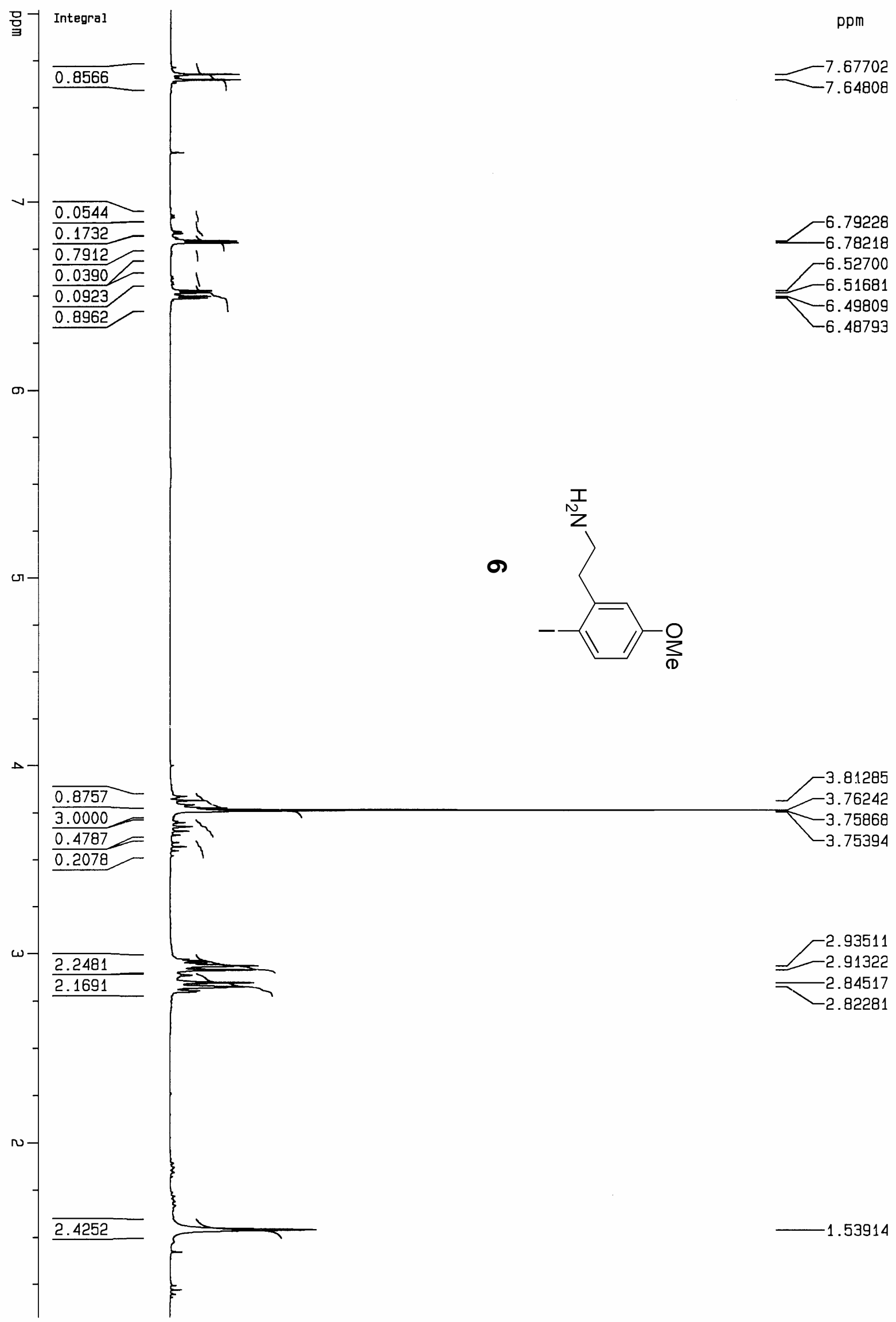


总

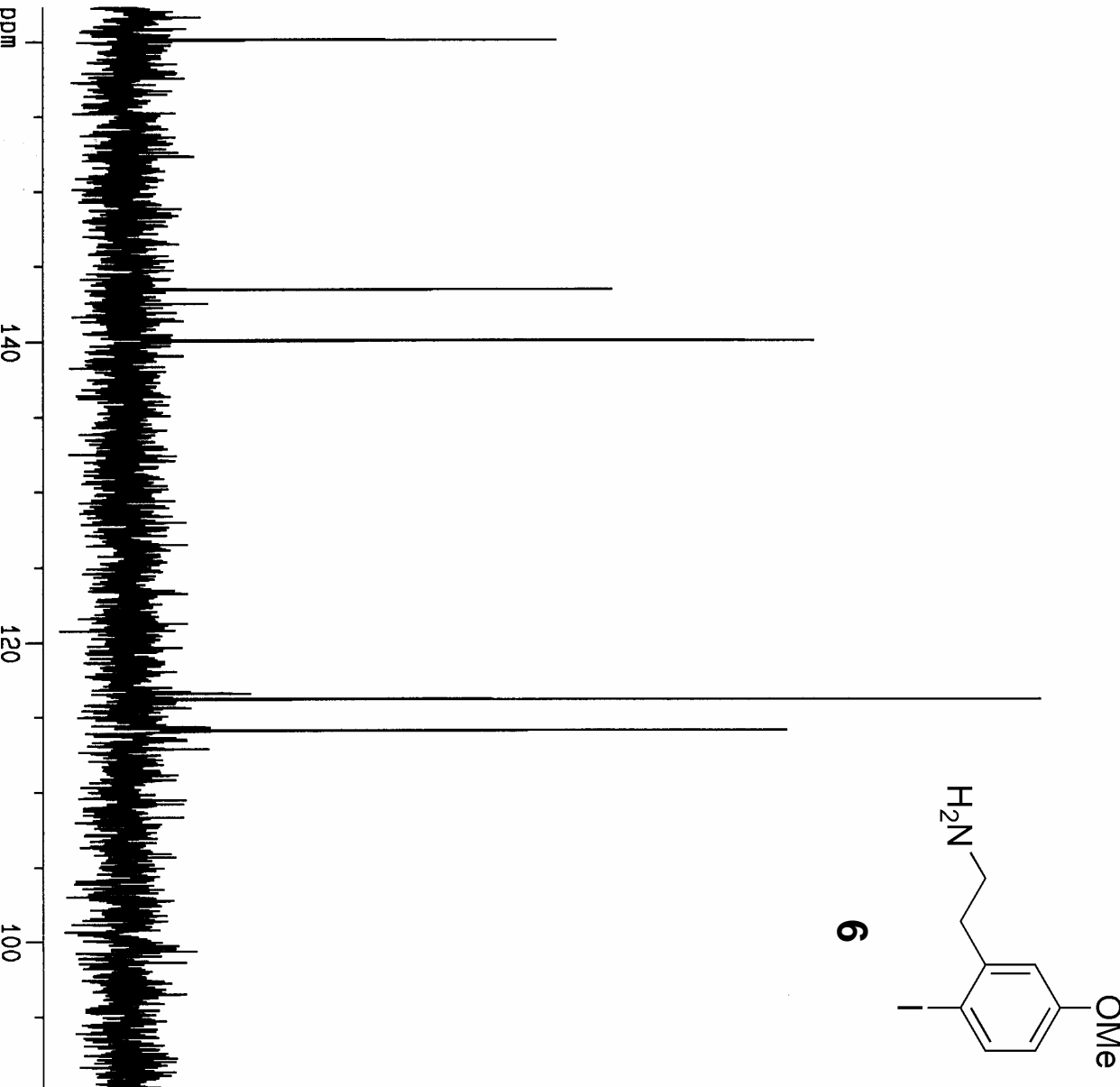

$-116.609$

116.234

$-114.142$

89.438

77.651

77.228

76.804

62.033

61.868

55.505

44.859

44.113

42.464

30.183 
믘

읔

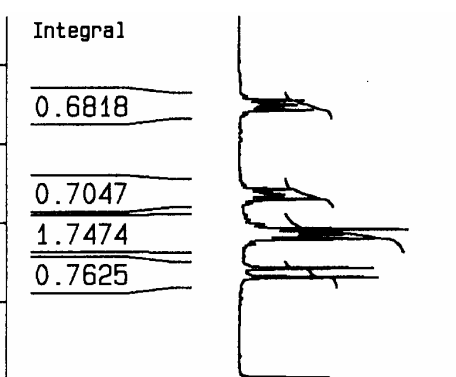

0.0391

0.8208

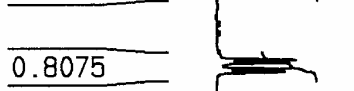

2.7573

0.2411

2.0000

1.9790

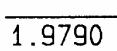

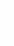
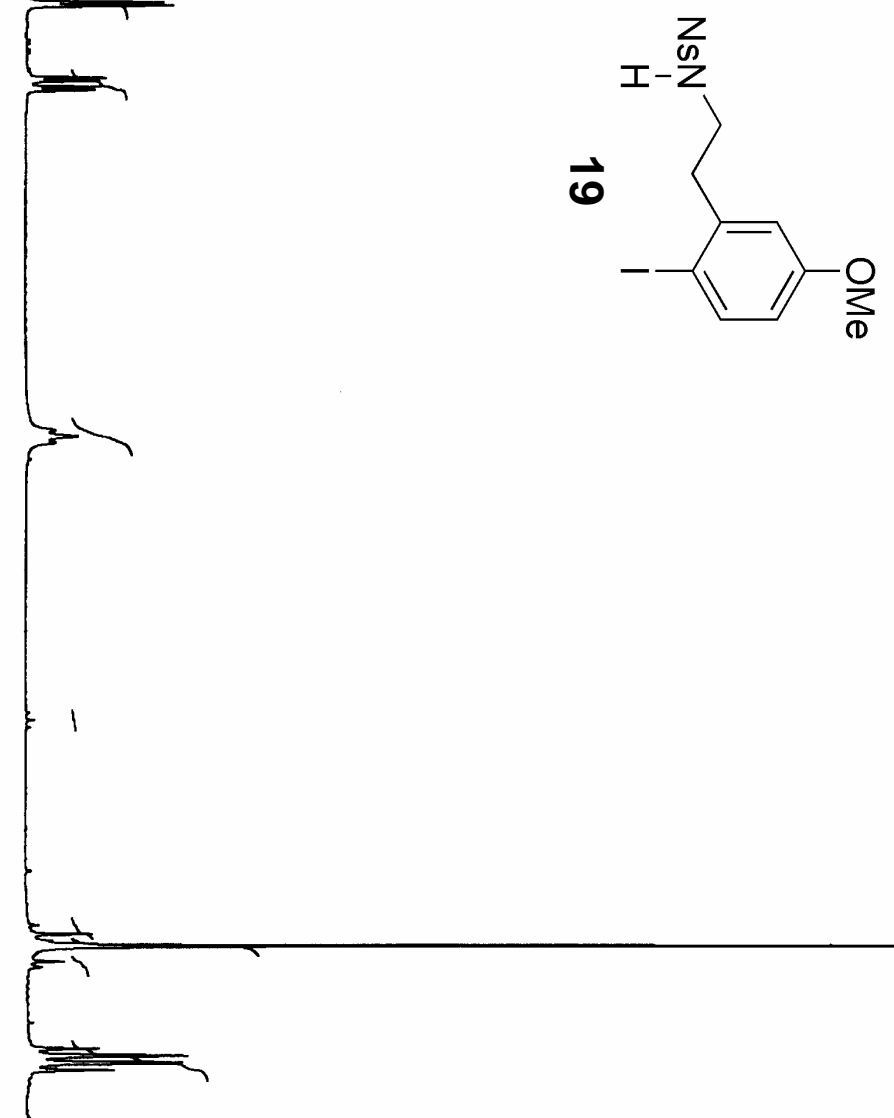

ppm

$-8.13634$

$-8.10547$

$\begin{array}{r}7.72923 \\ -7.71536 \\ \hline\end{array}$

$-7.60684$

$-7.57785$

7.26027

6.74412

6.73412

$-6.50563$

$-6.49559$

$-6.47667$

$-6.46663$

$-5.37078$
$-3.79318$

3.76239

$-3.75494$

$-3.40756$

$-3.38627$

$-3.38457$

$-3.36292$

$-2.94939$

2.92532

$-2.90175$ 


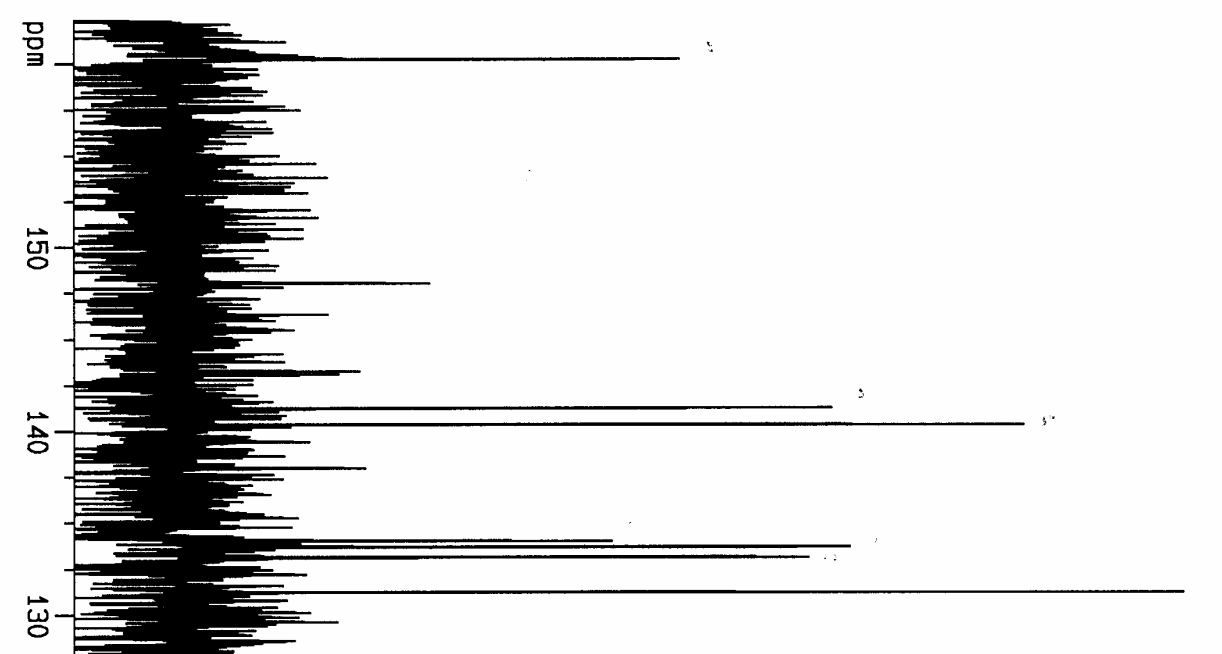

긍

$=$

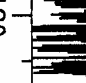

$=$

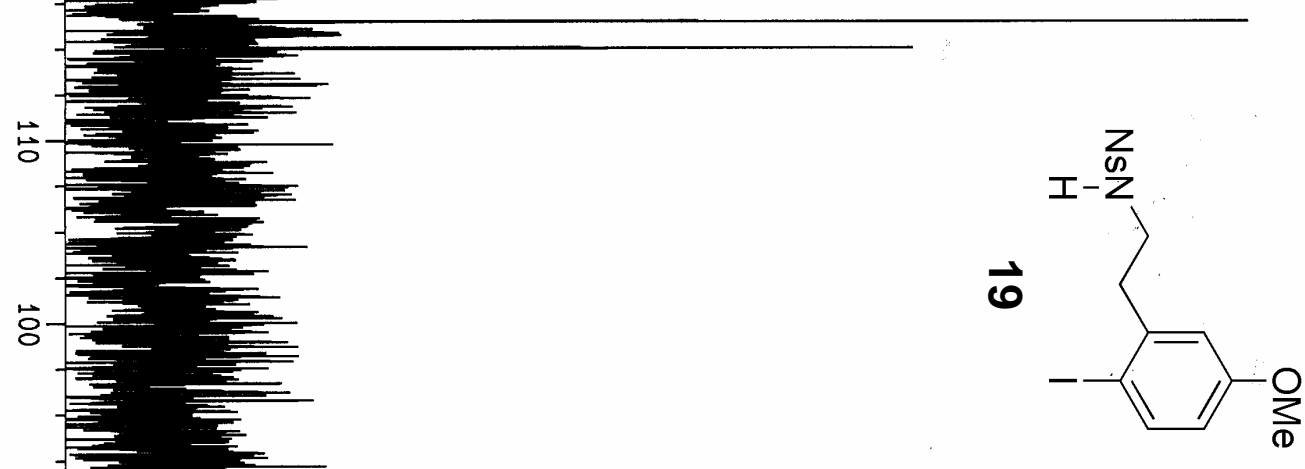

$-116.470$

$-115.036$

电

o

\%

层

77.652

77.228

76.805

$\checkmark$
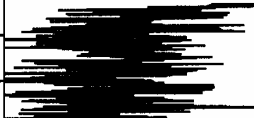

工

=
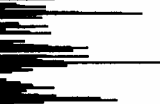

g

$=$

$=$

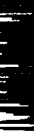

Е

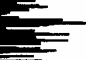

당

$=$

$=$

$\equiv$

o-

$\equiv$

$=$

43.622

41.020 


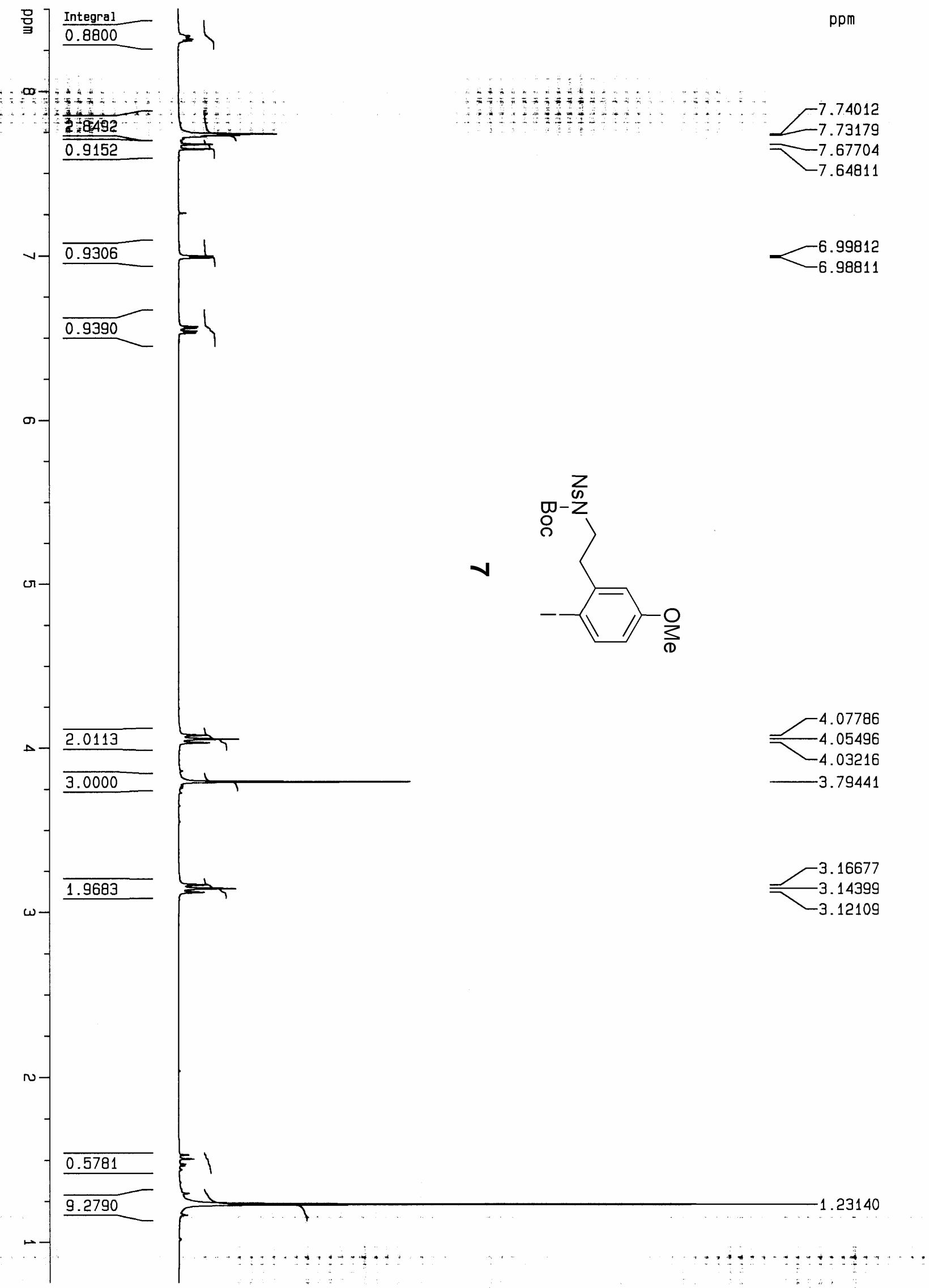



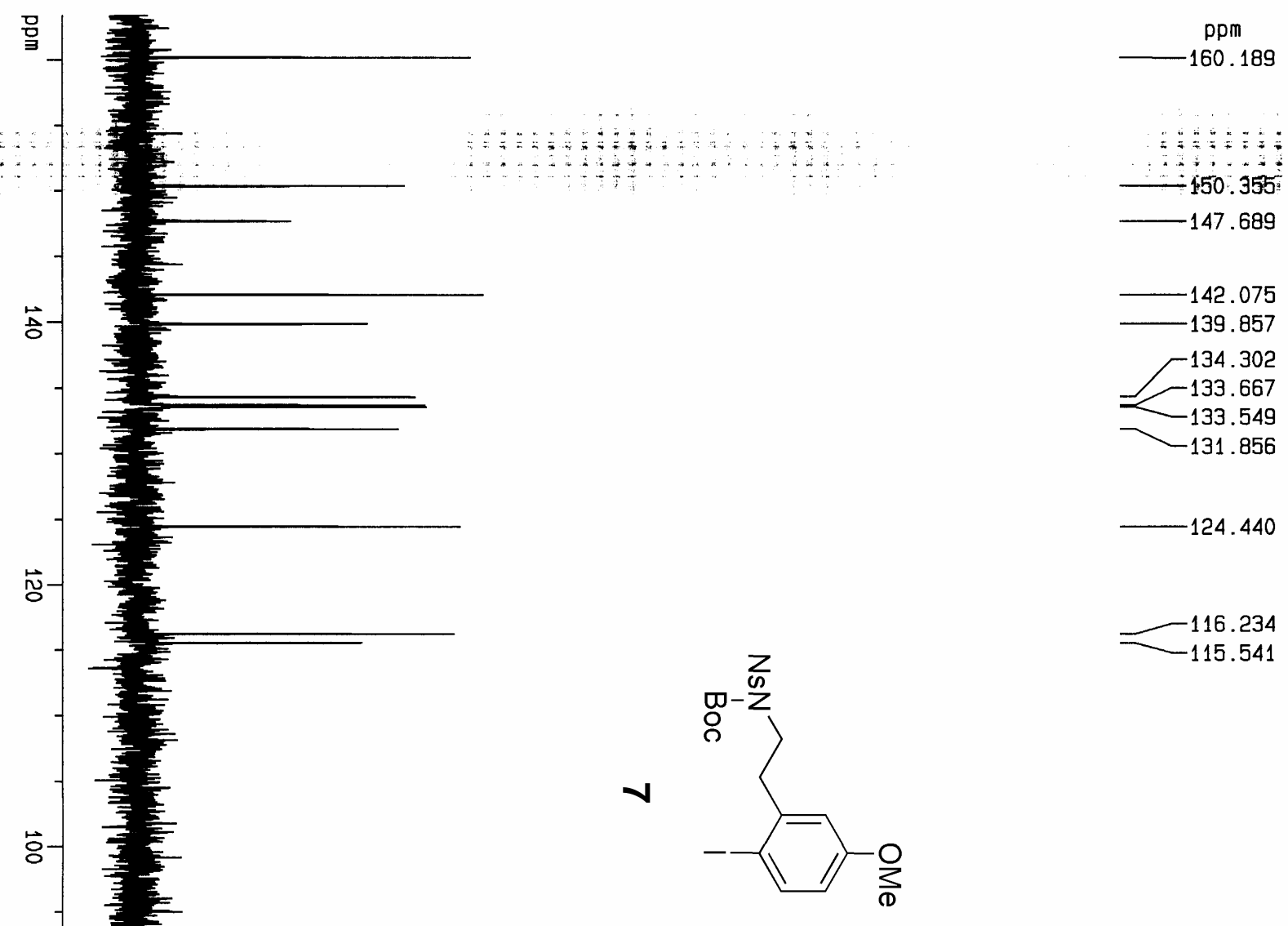

139.857

$-134.302$

$-133.667$

$-133.549$

$-131.856$

$-124.440$

$-116.234$

$-115.541$

89.192

84.914

77.579

77.155

76.732

55.546

47.434

41.637

27.811 


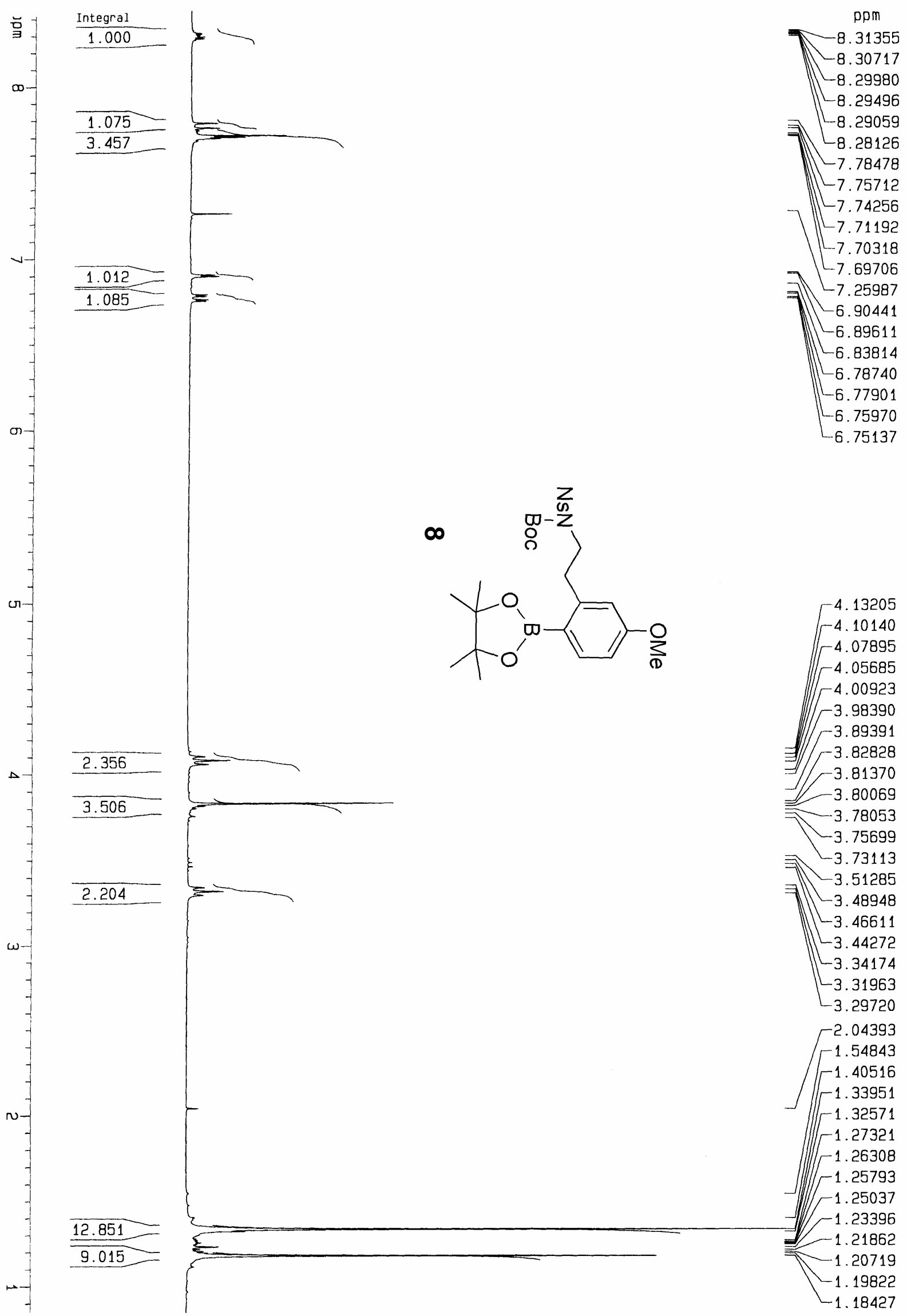




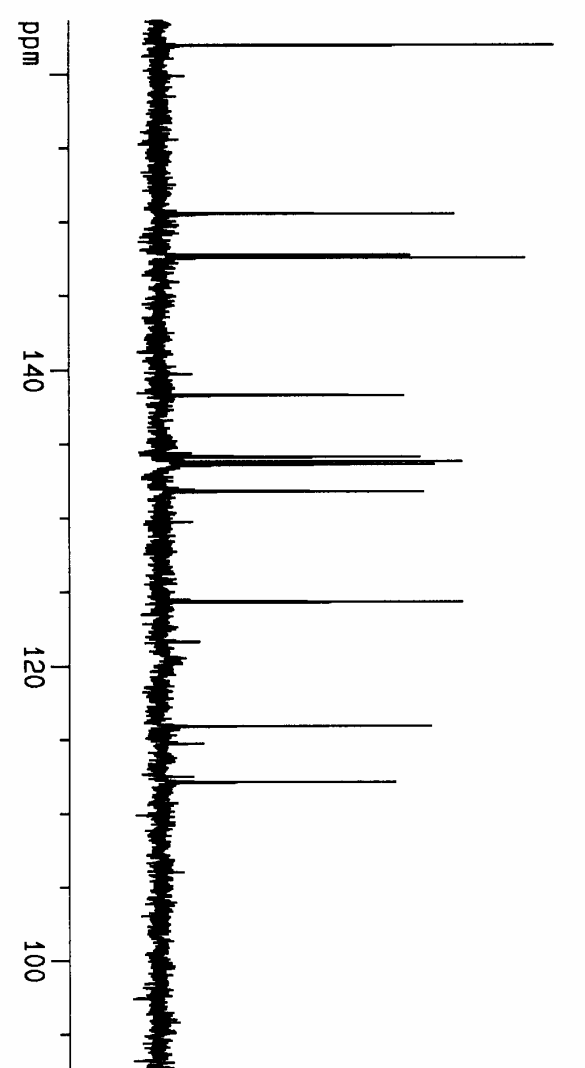

ppm

$-161.973$

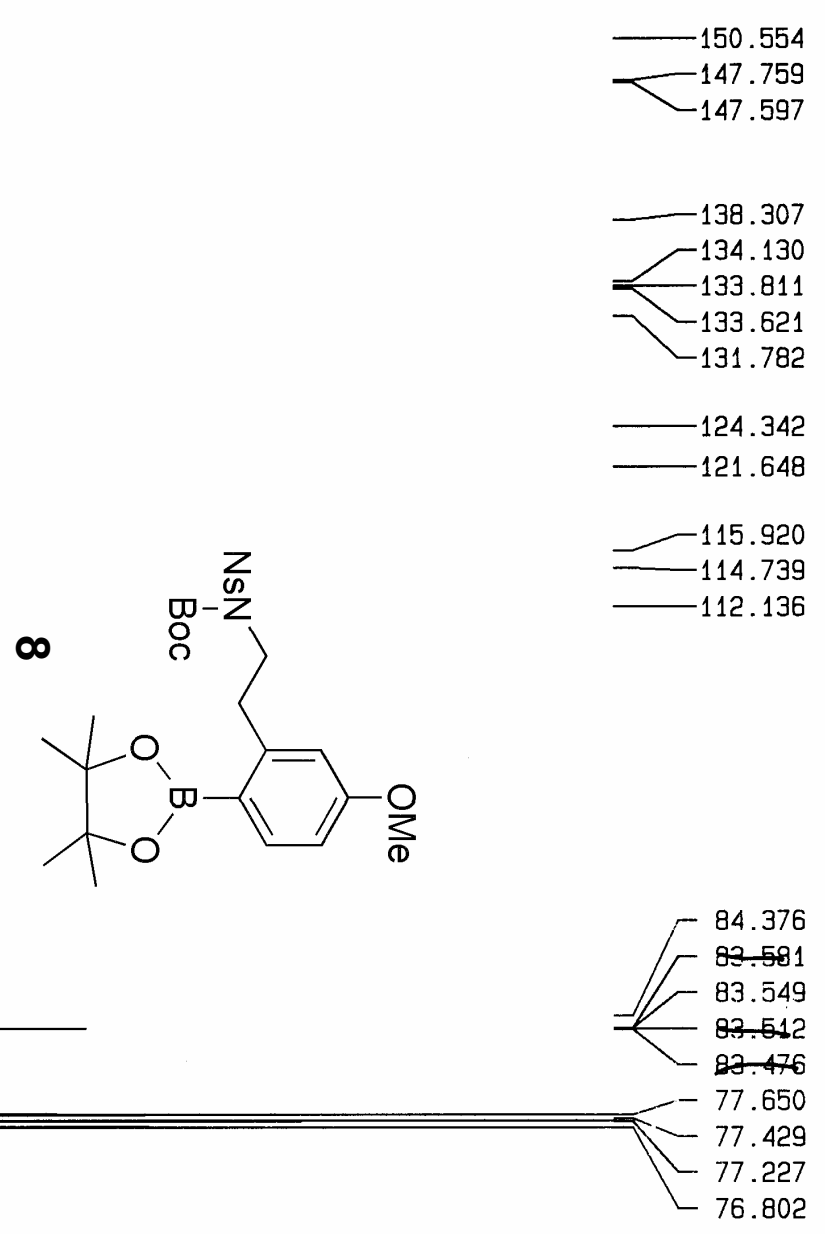

吅

60.558

g

55.302

49.781

36.754

ㅇ

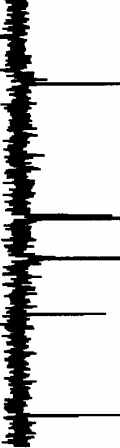

27.907

27.837

$-27.740$

$-24.987$

ก

21.220 


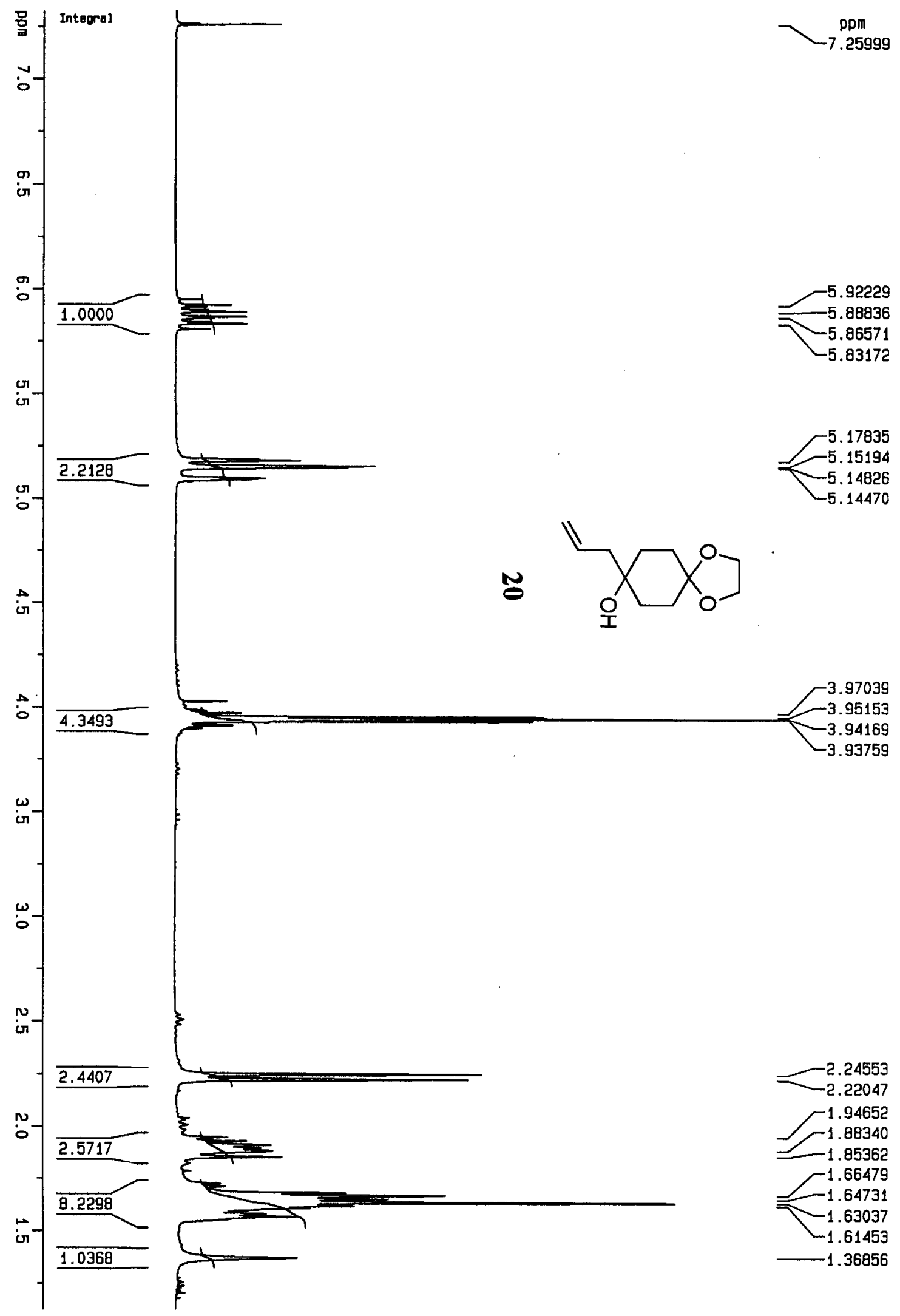




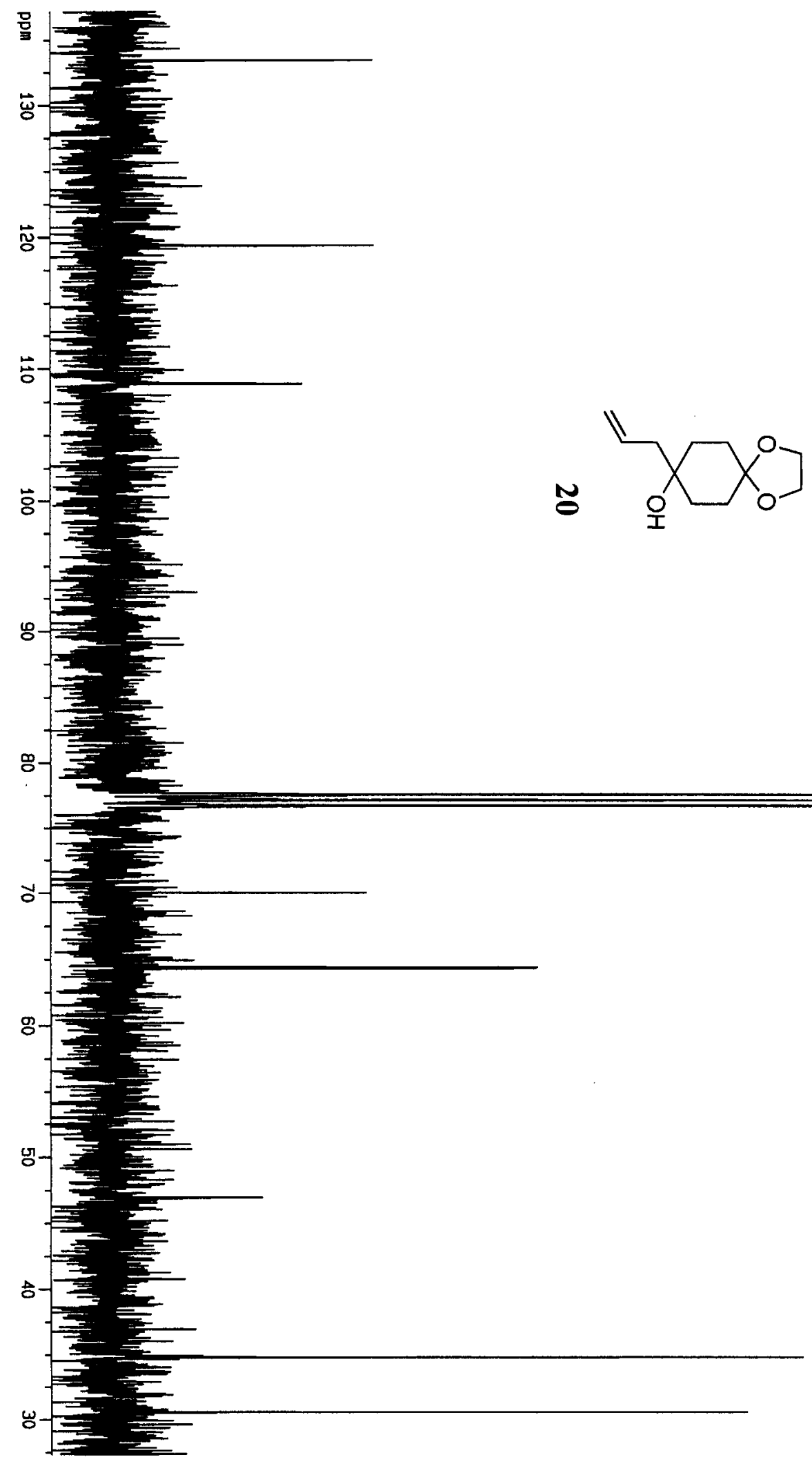




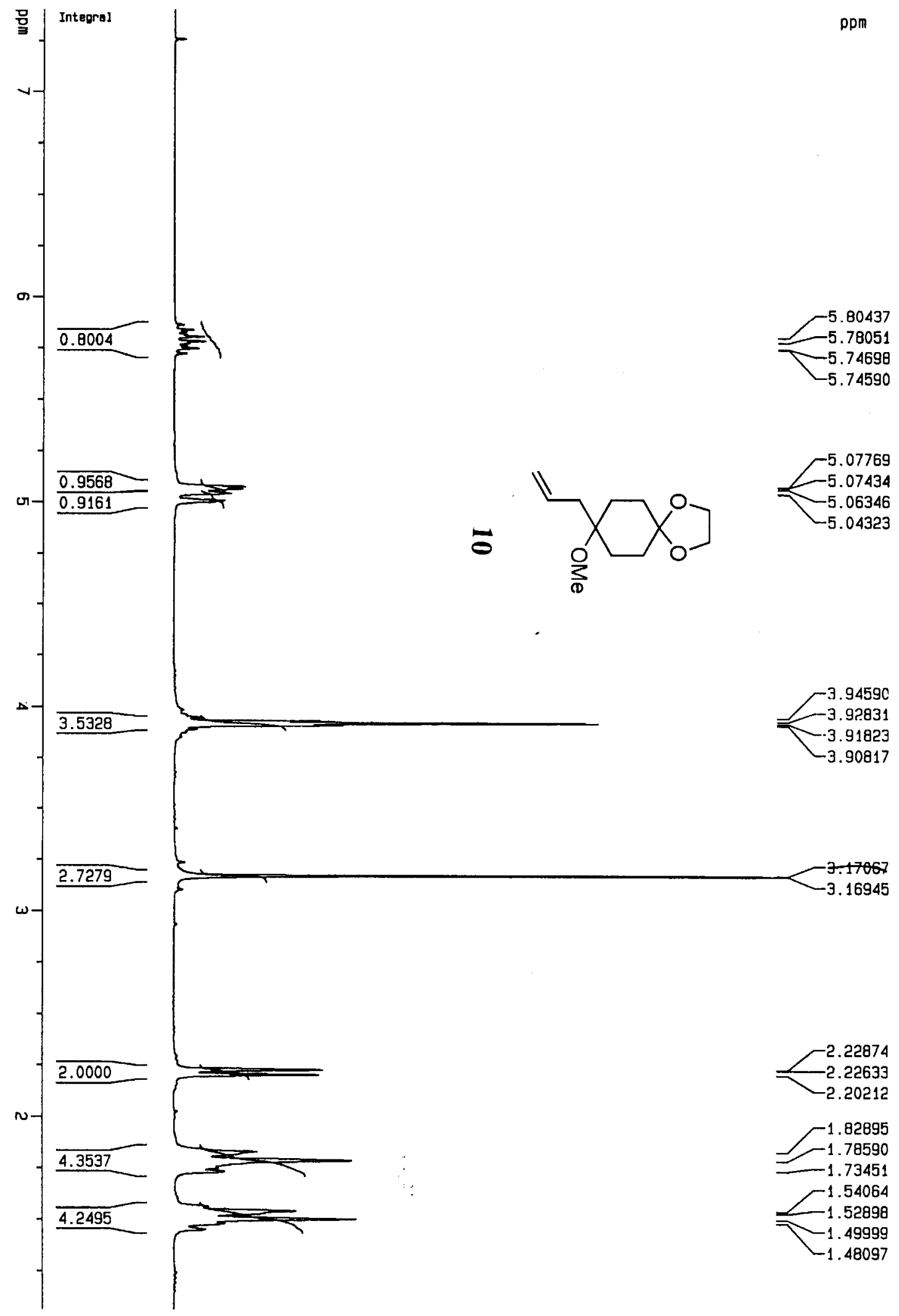




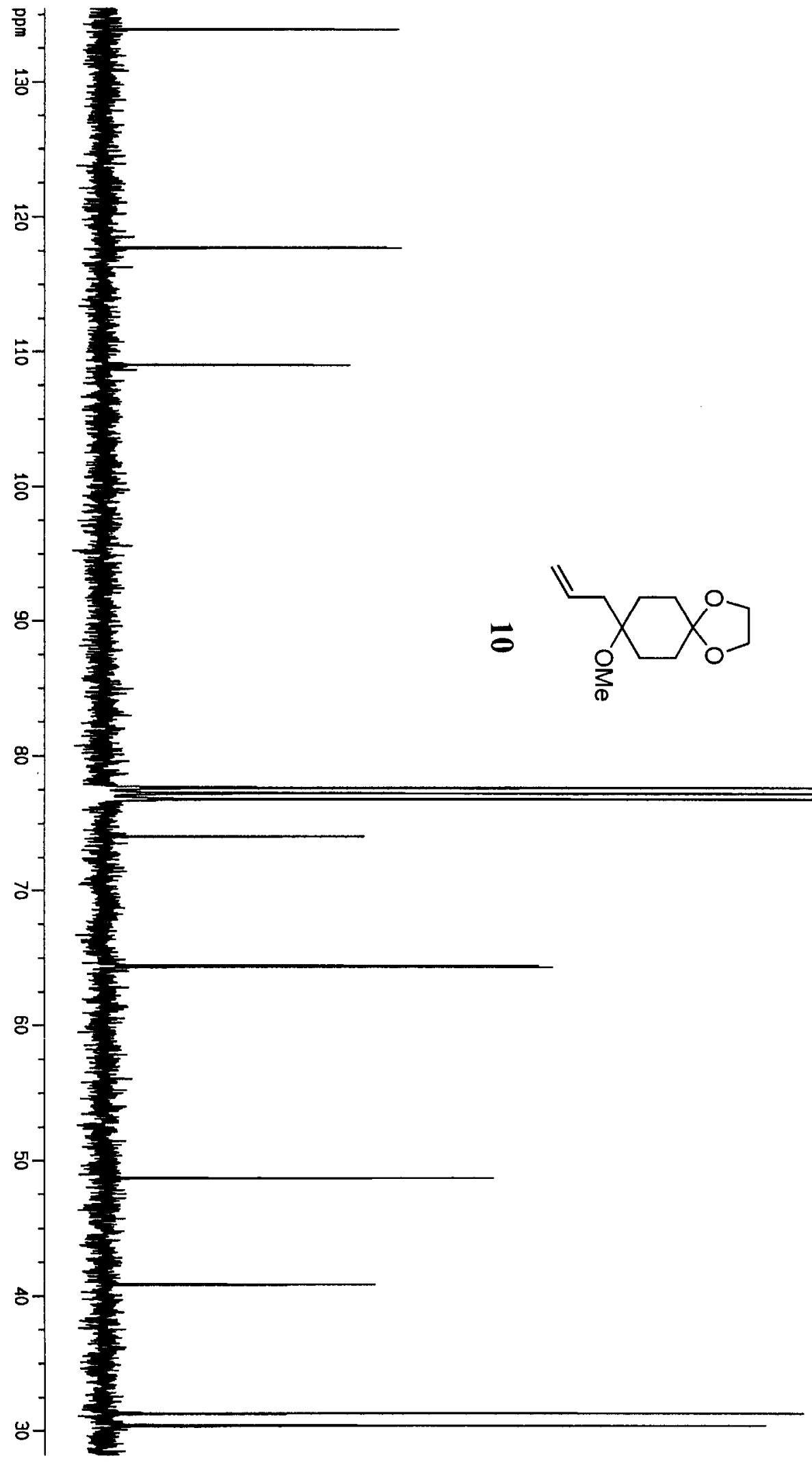

77.651

77.227

76.804

74.024

64.451

64.345

48.702

40.856

-31.265
$=30.349$ 


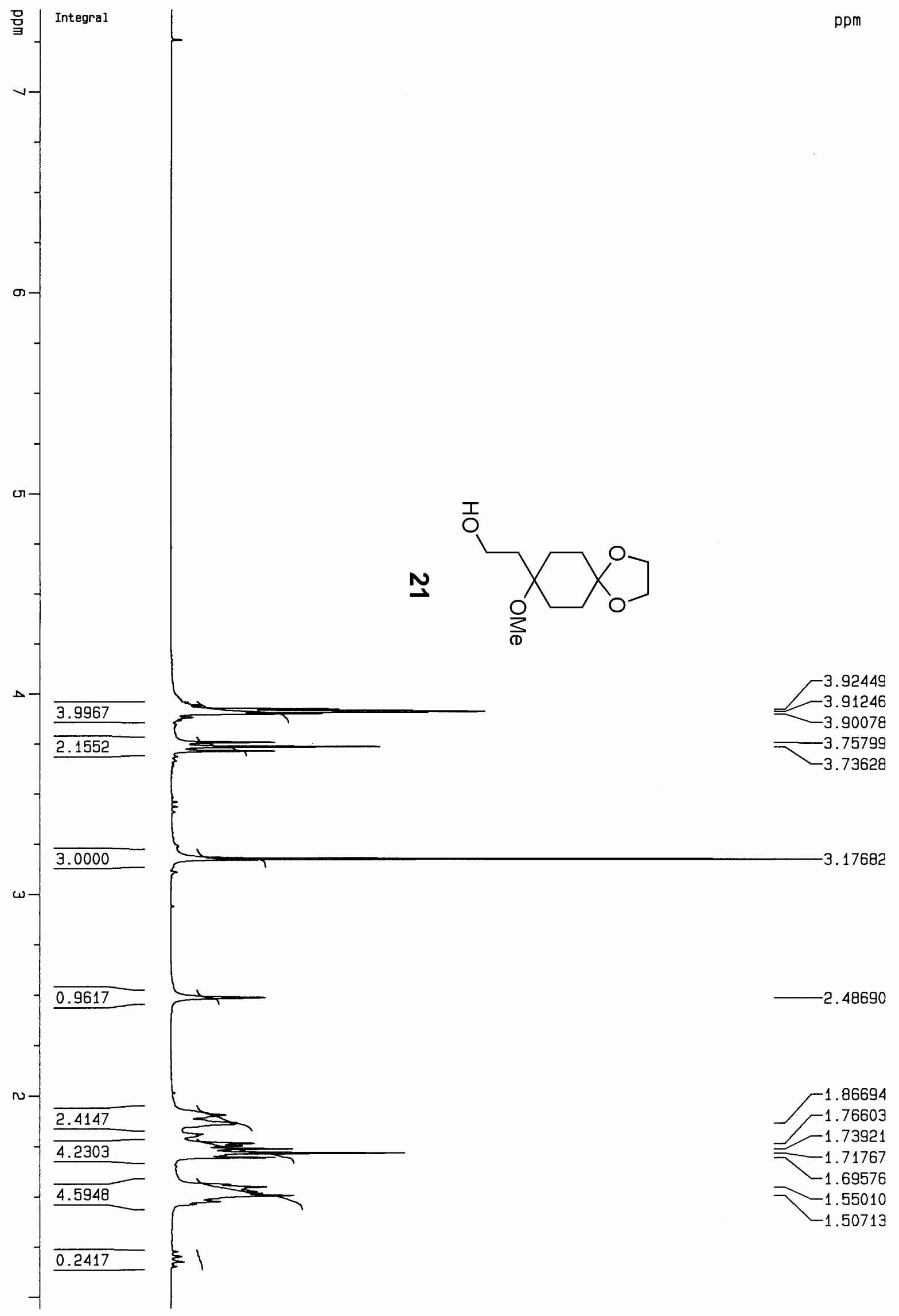




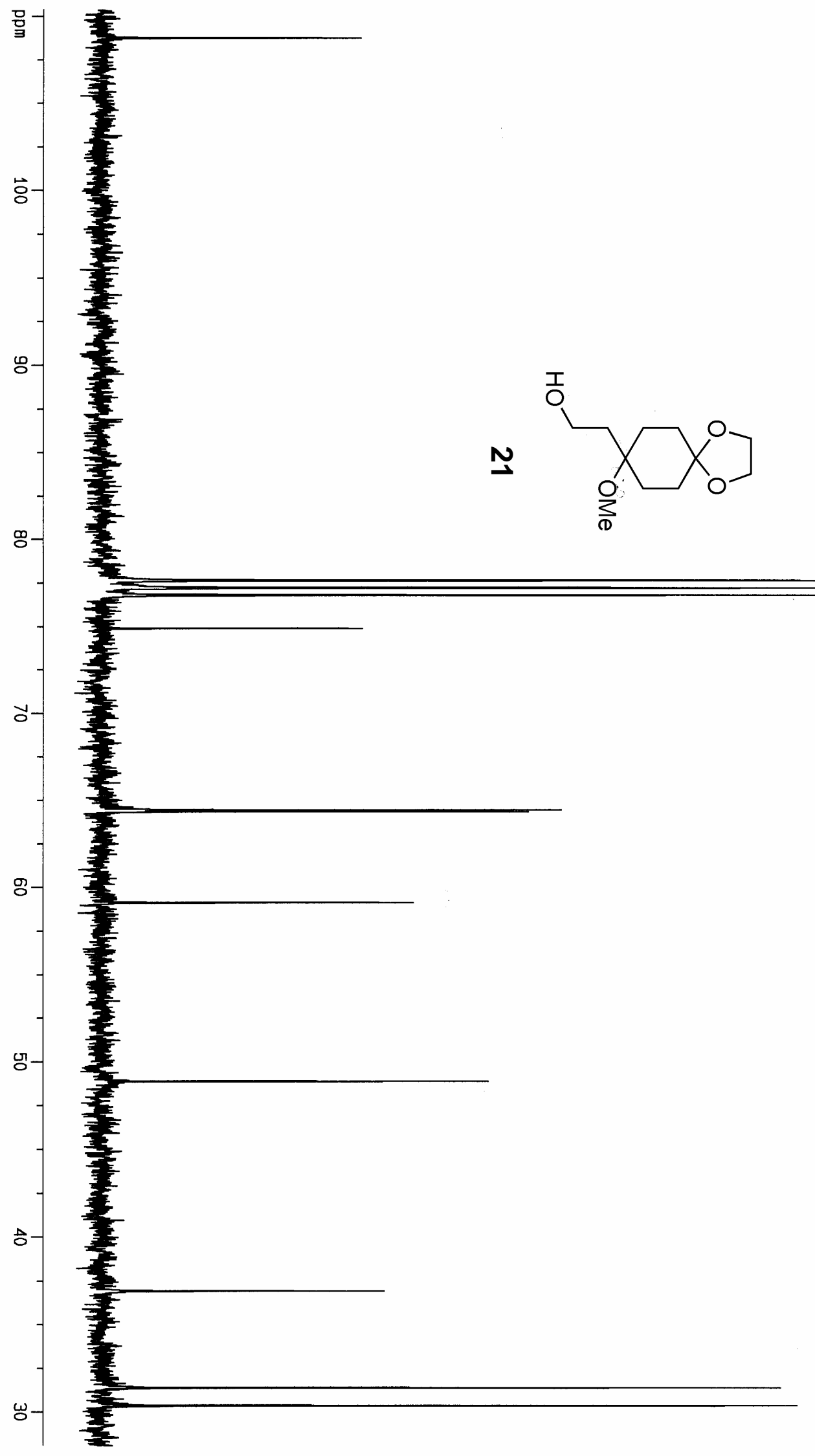




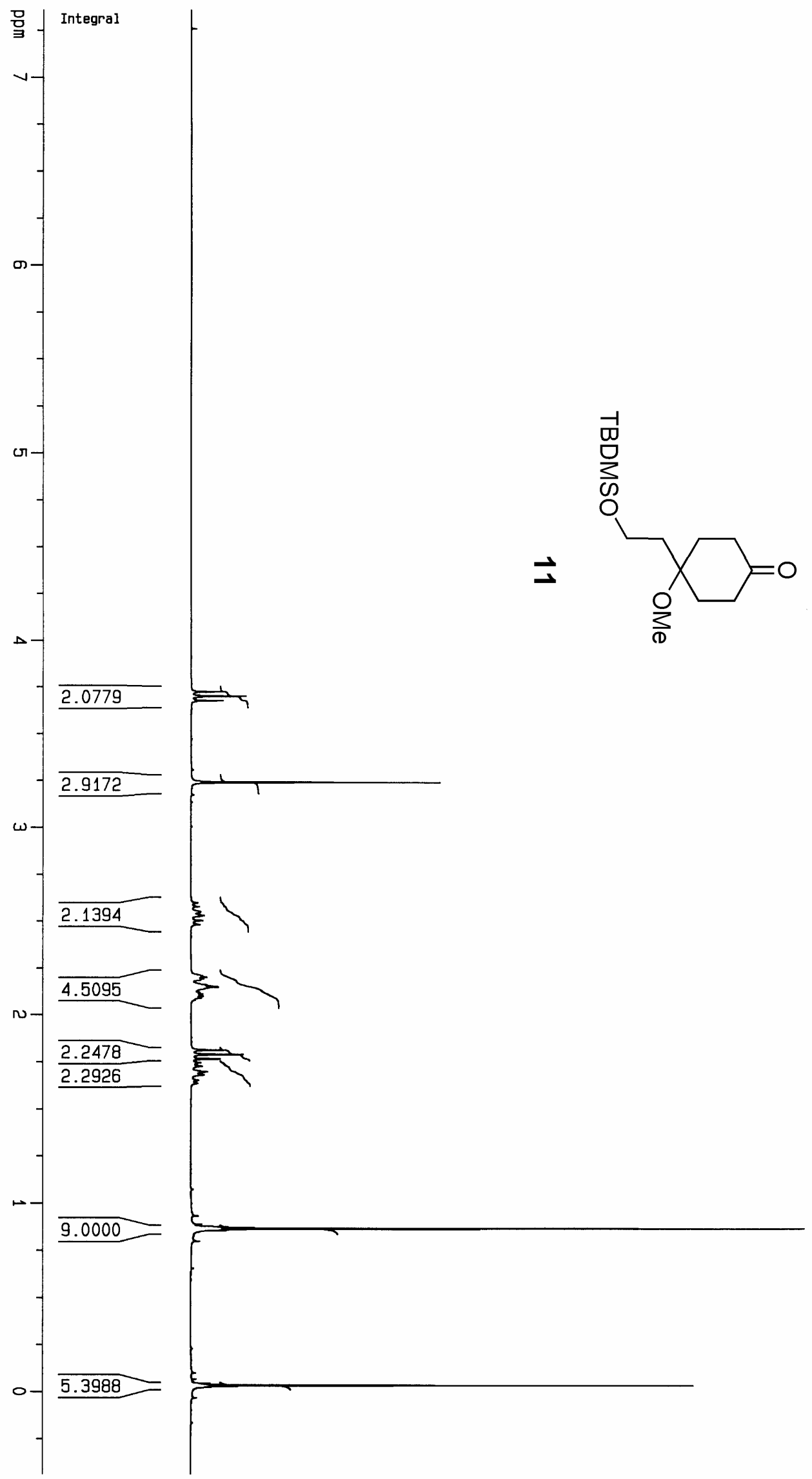

3.72412

3.70031

$-3.67631$

$-3.24078$

$-2.15027$

2.14723

$-1.81293$

1.78907

1.76526

$-0.86492$

$\sim 0.85539$

$-0.03435$ 


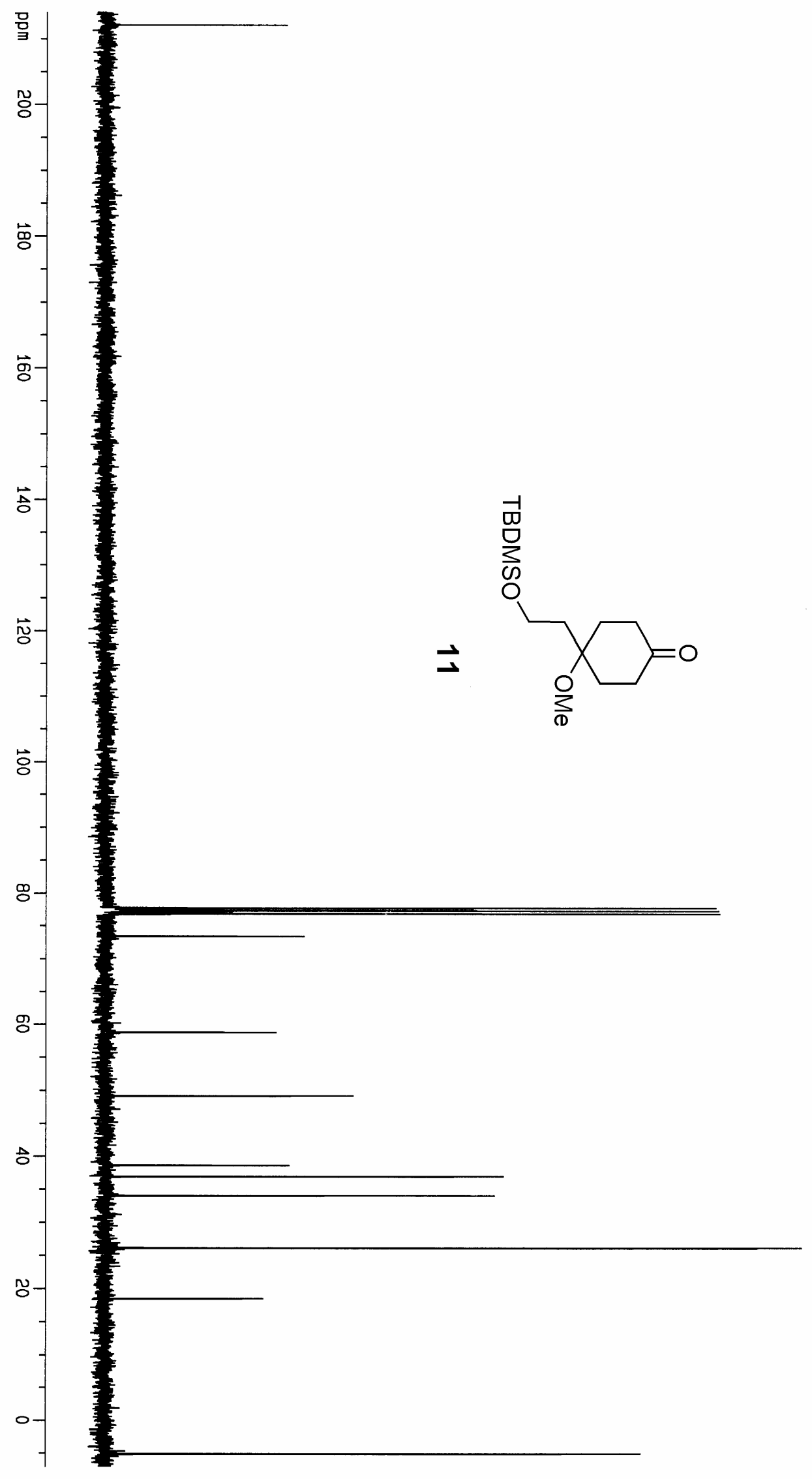

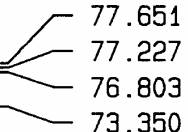

$-73.350$

58.728

49.104

38.579

36.877

33.961

26.457

26. 46

26.089

253

26. 2

18.422

$\digamma$\begin{tabular}{l}
-5.117 \\
-5.185 \\
$-\frac{5.222}{-5.252}$ \\
\hline
\end{tabular} 


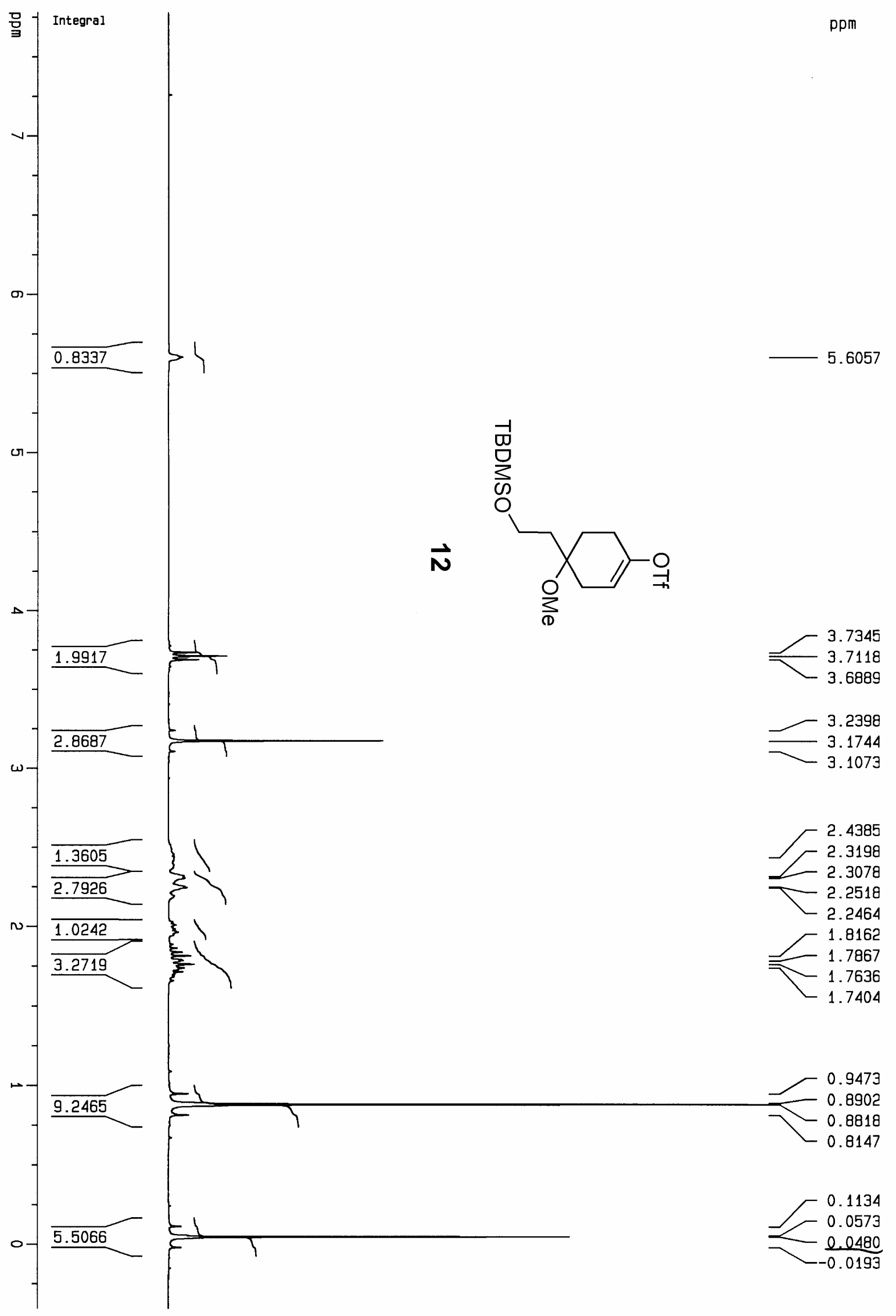




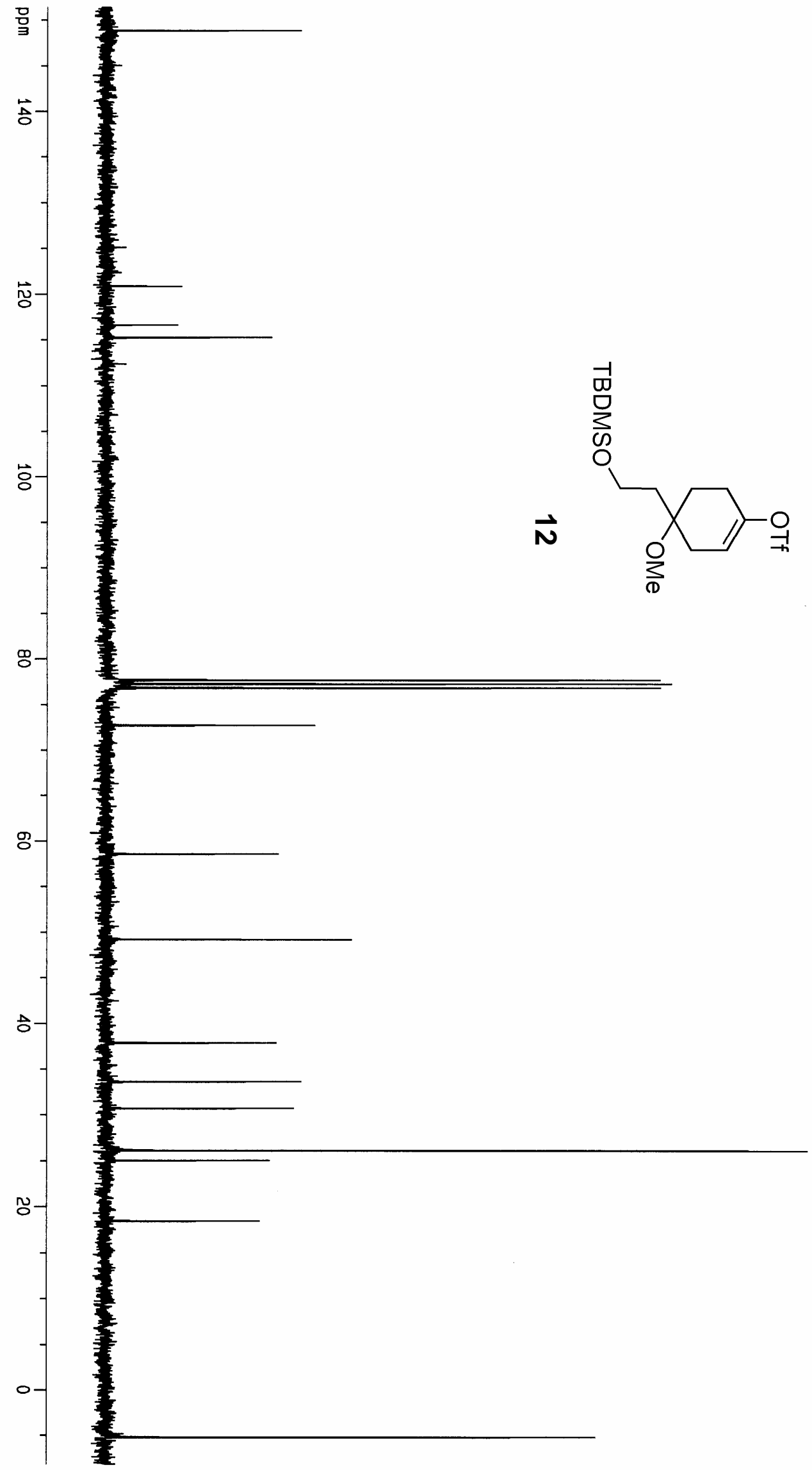

25.019

18.431 

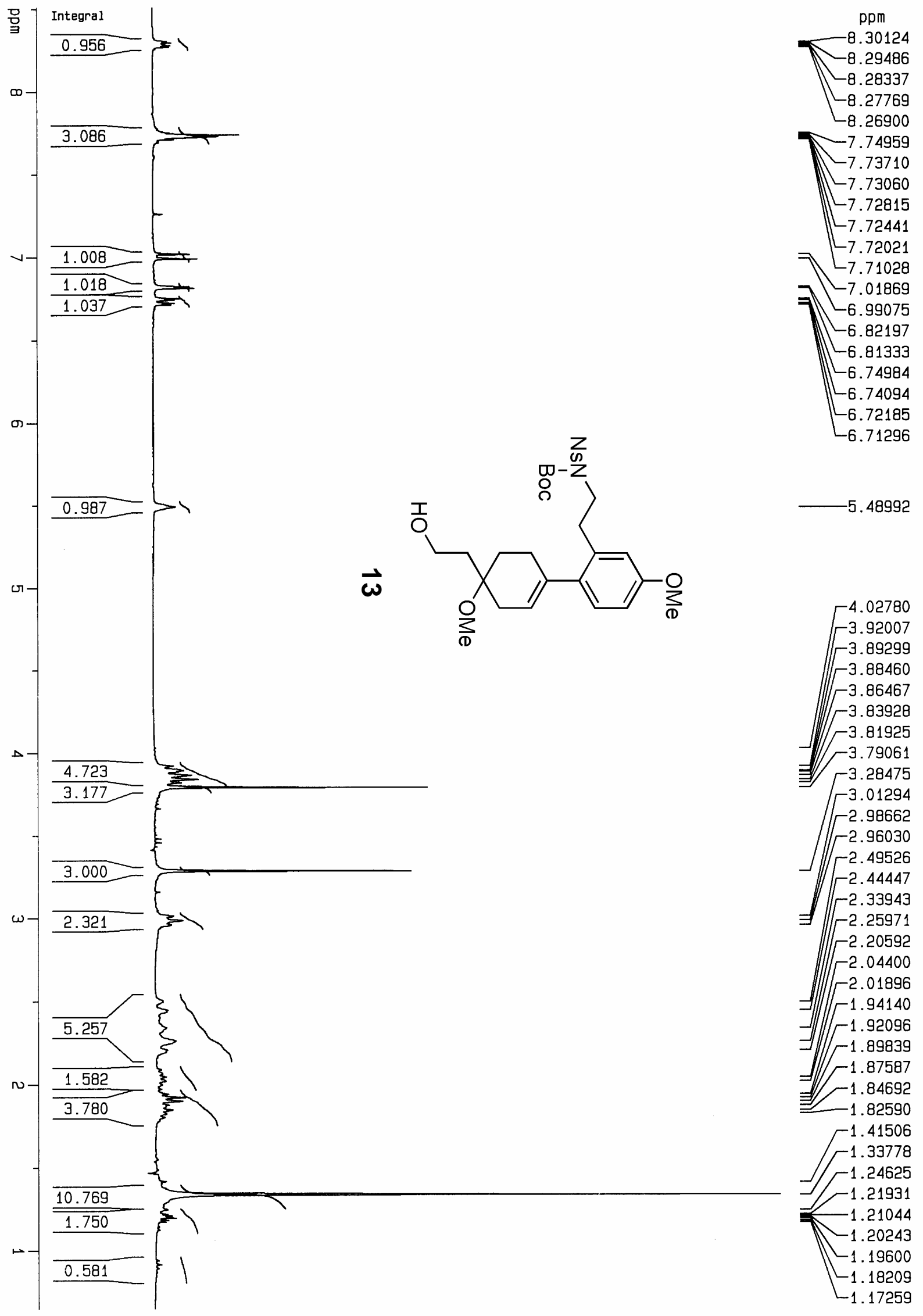

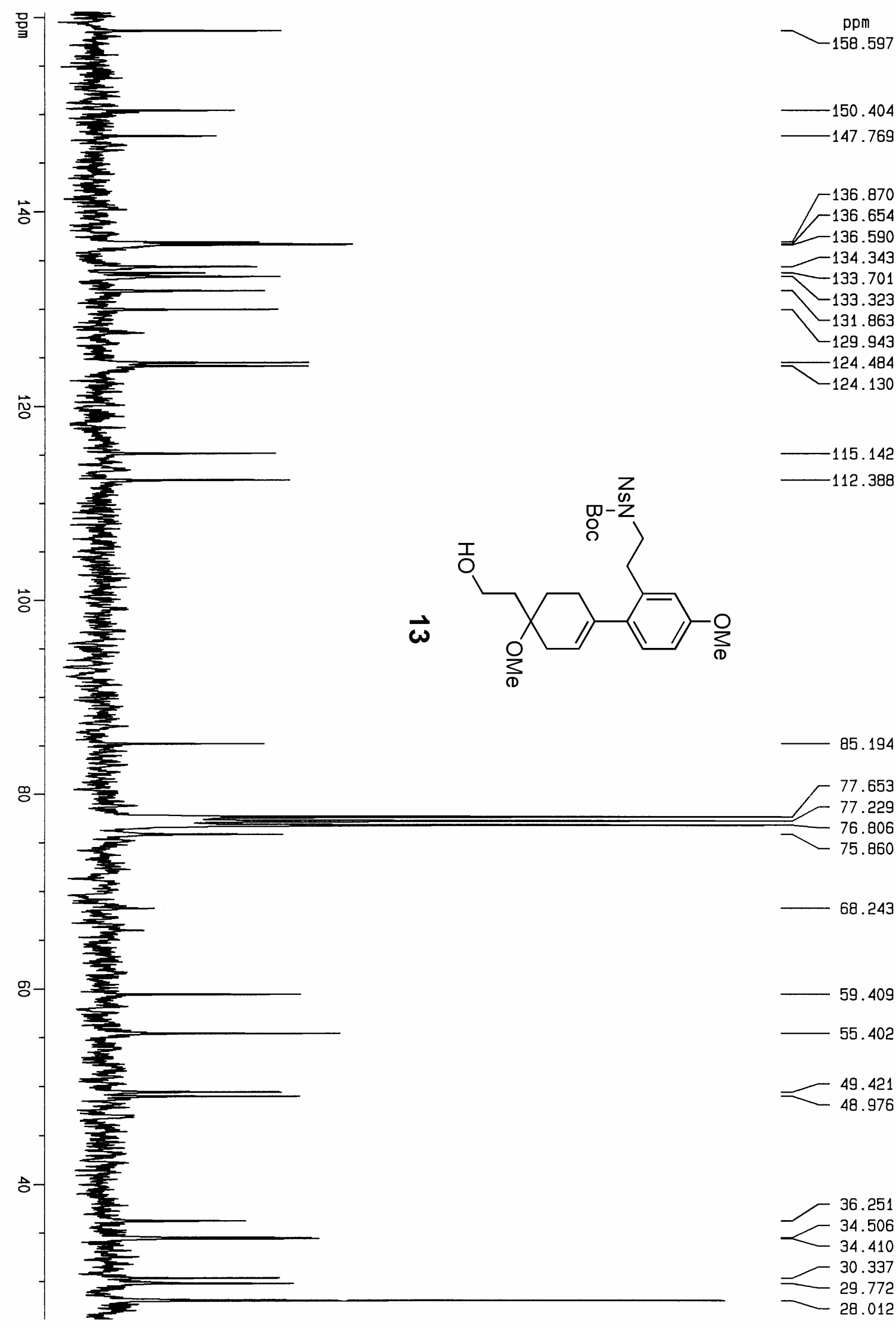

$-150.404$

147.769

136.870
-136.654

$-136.590$

$-134.343$

$-133.701$

$-133.323$

$-131.863$

$-129.943$

$-124.484$

$-124.130$

N

95.194

77.653

$-77.229$

76.806

75.860

68.243

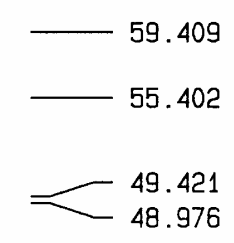

9.409

.421

48.976

$-36.251$

34.506

34.410

30.337

$\begin{array}{r}39.772 \\ \hline\end{array}$

-
$-\quad 28.012$ 


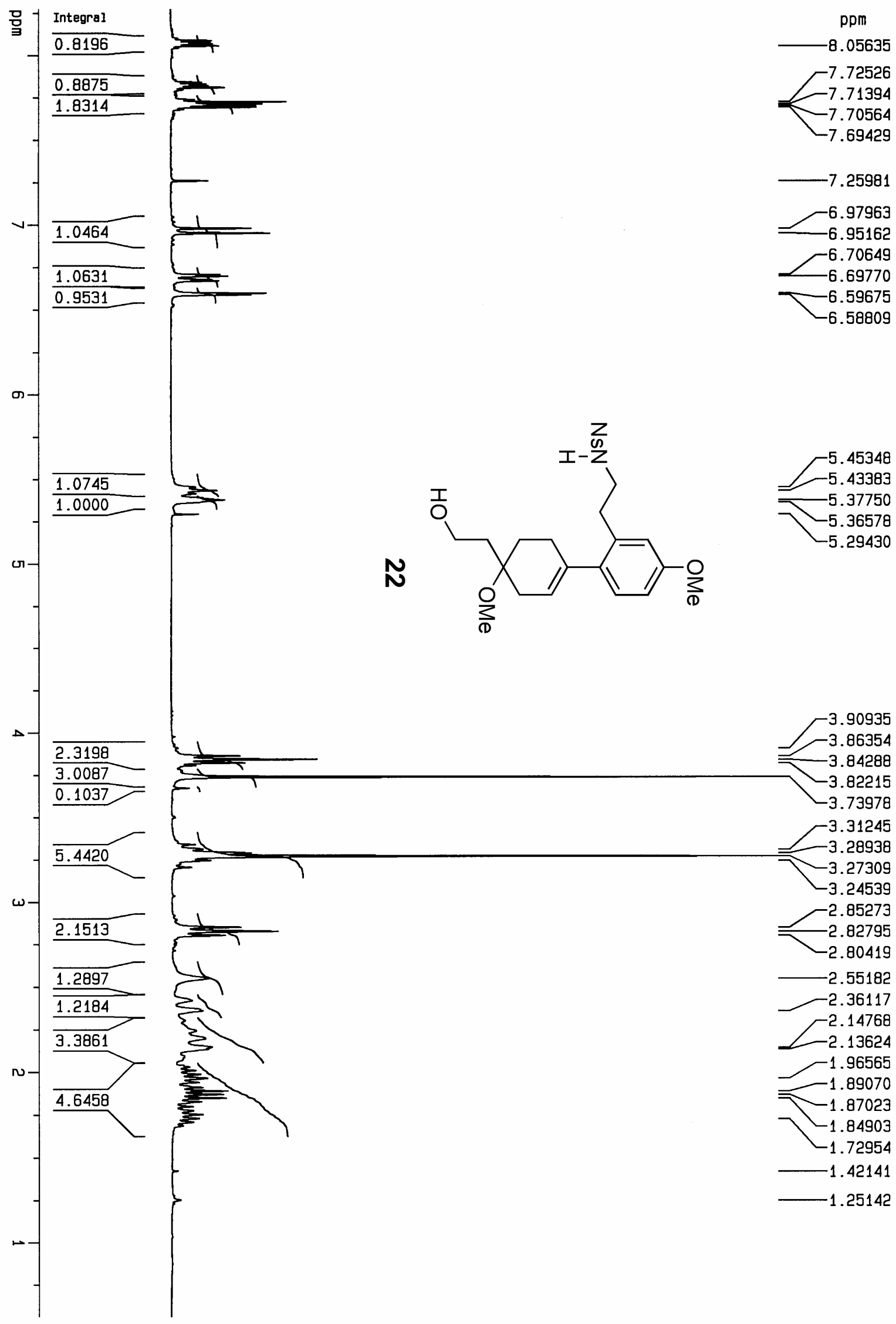




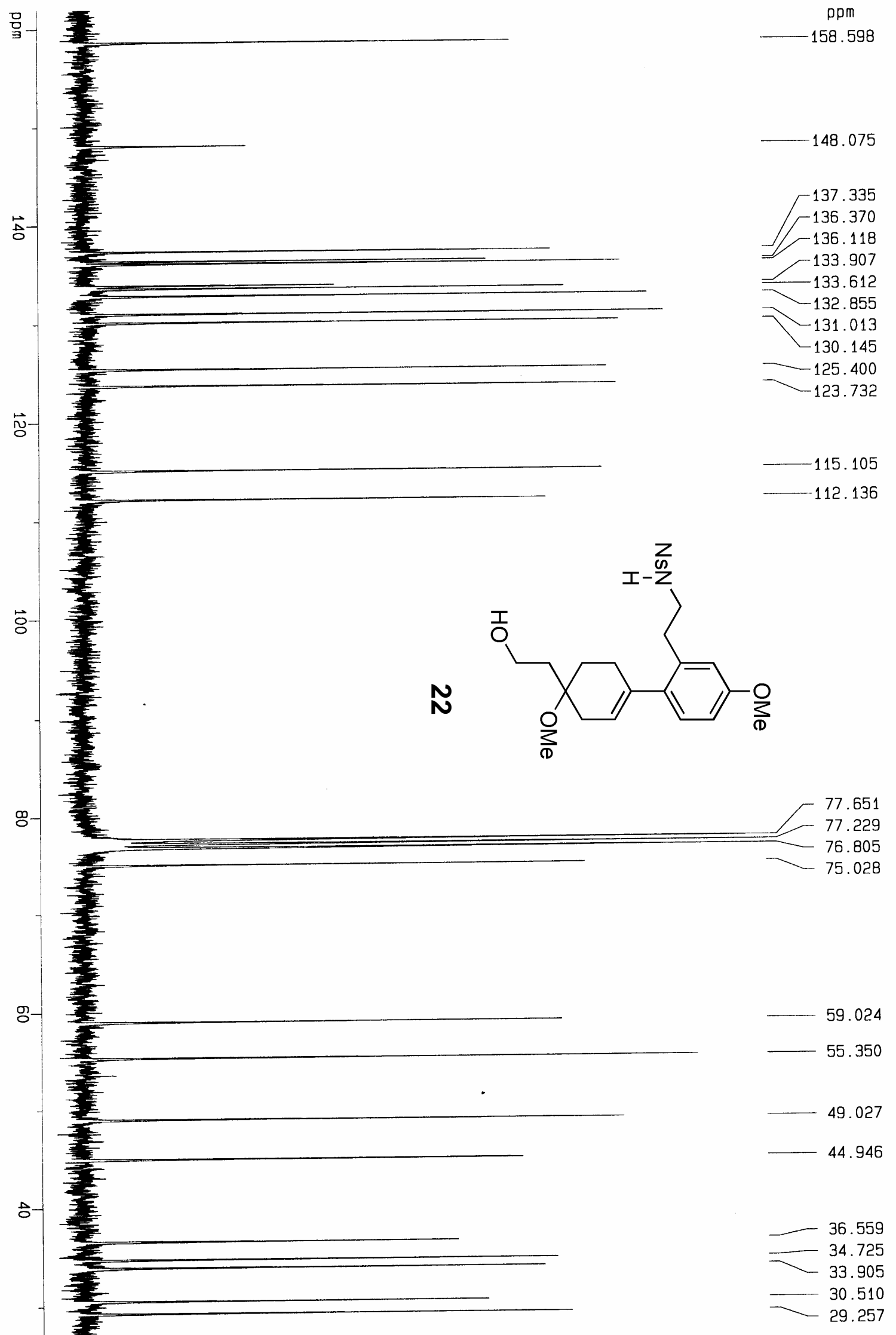




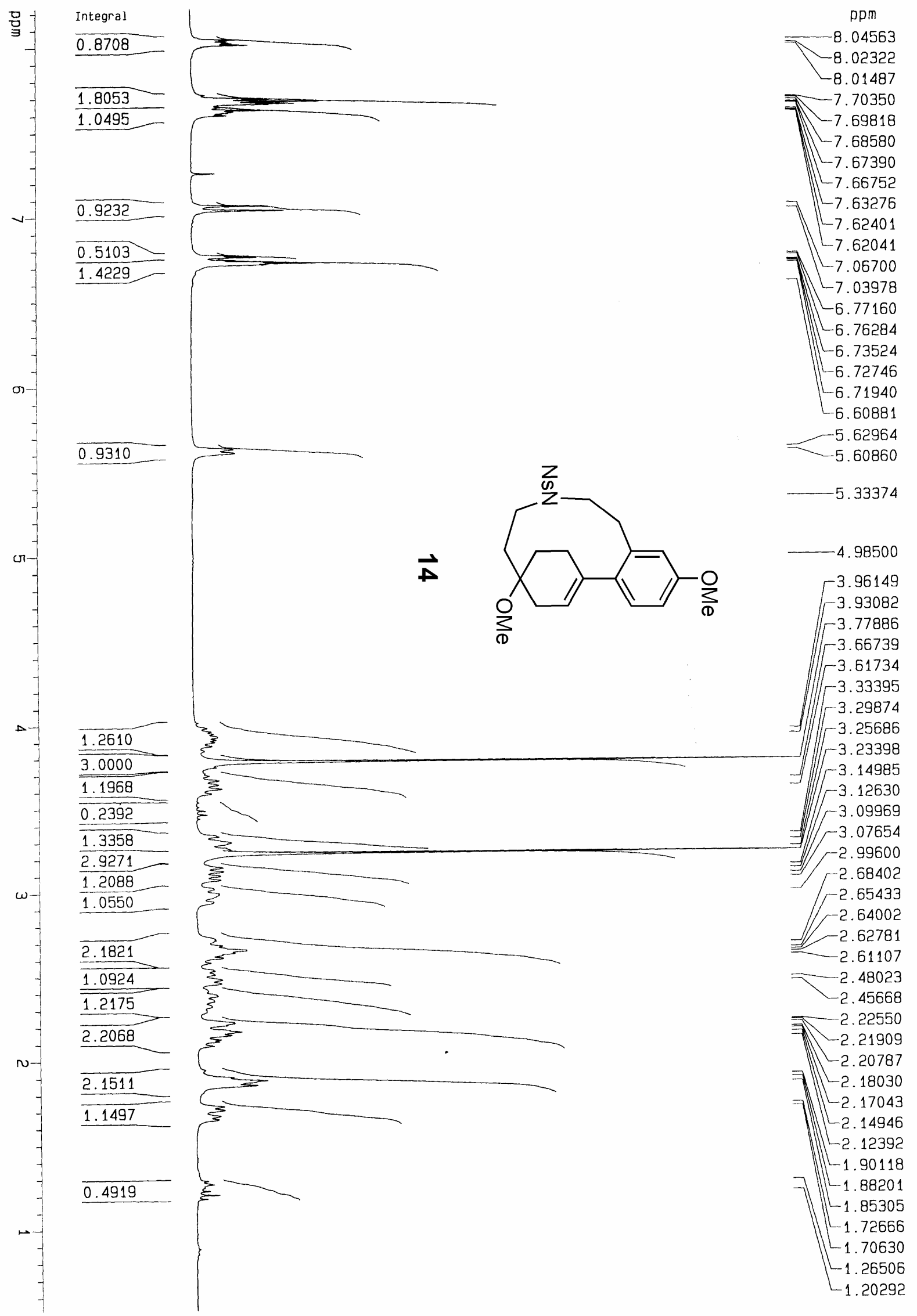




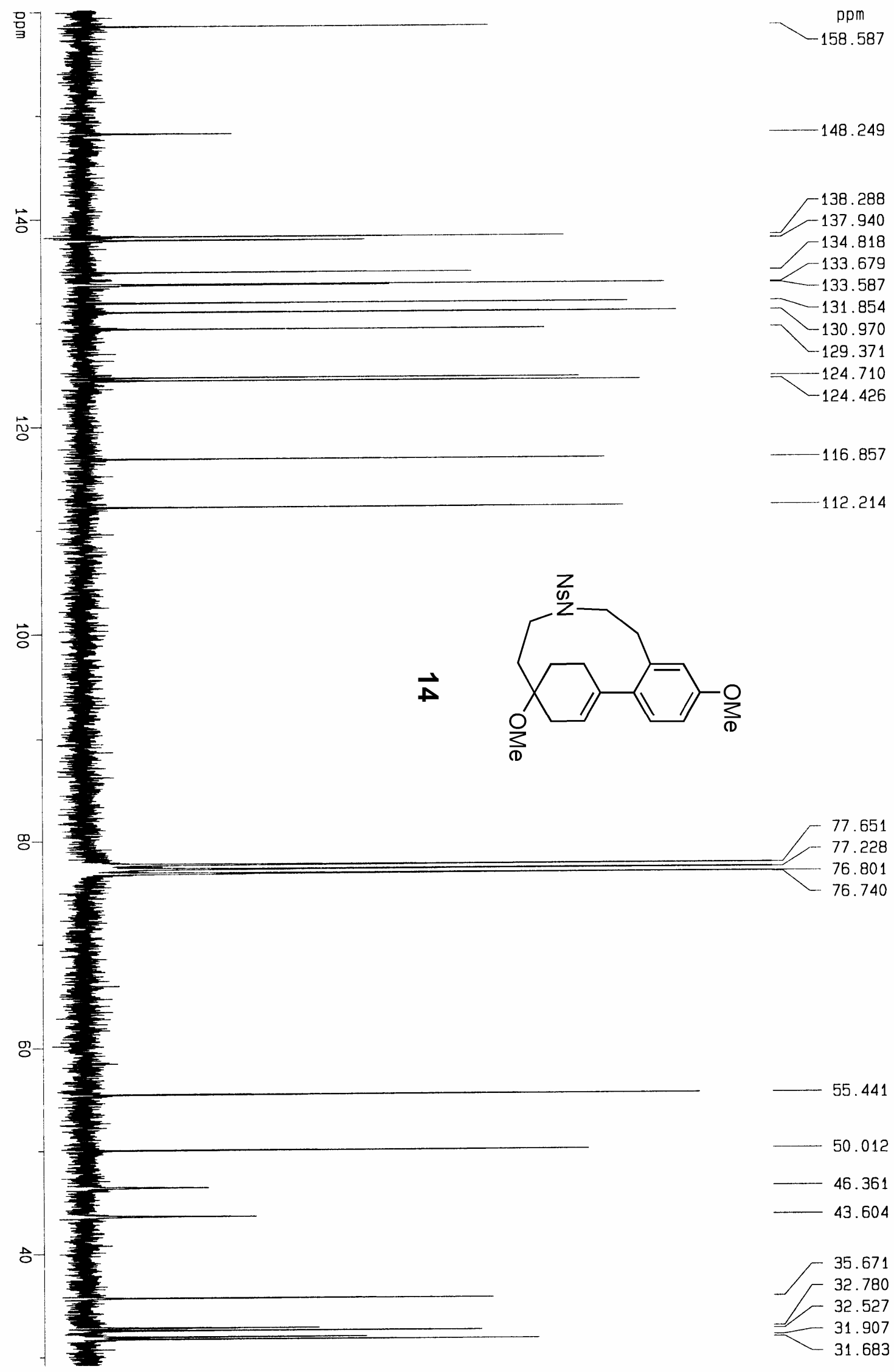




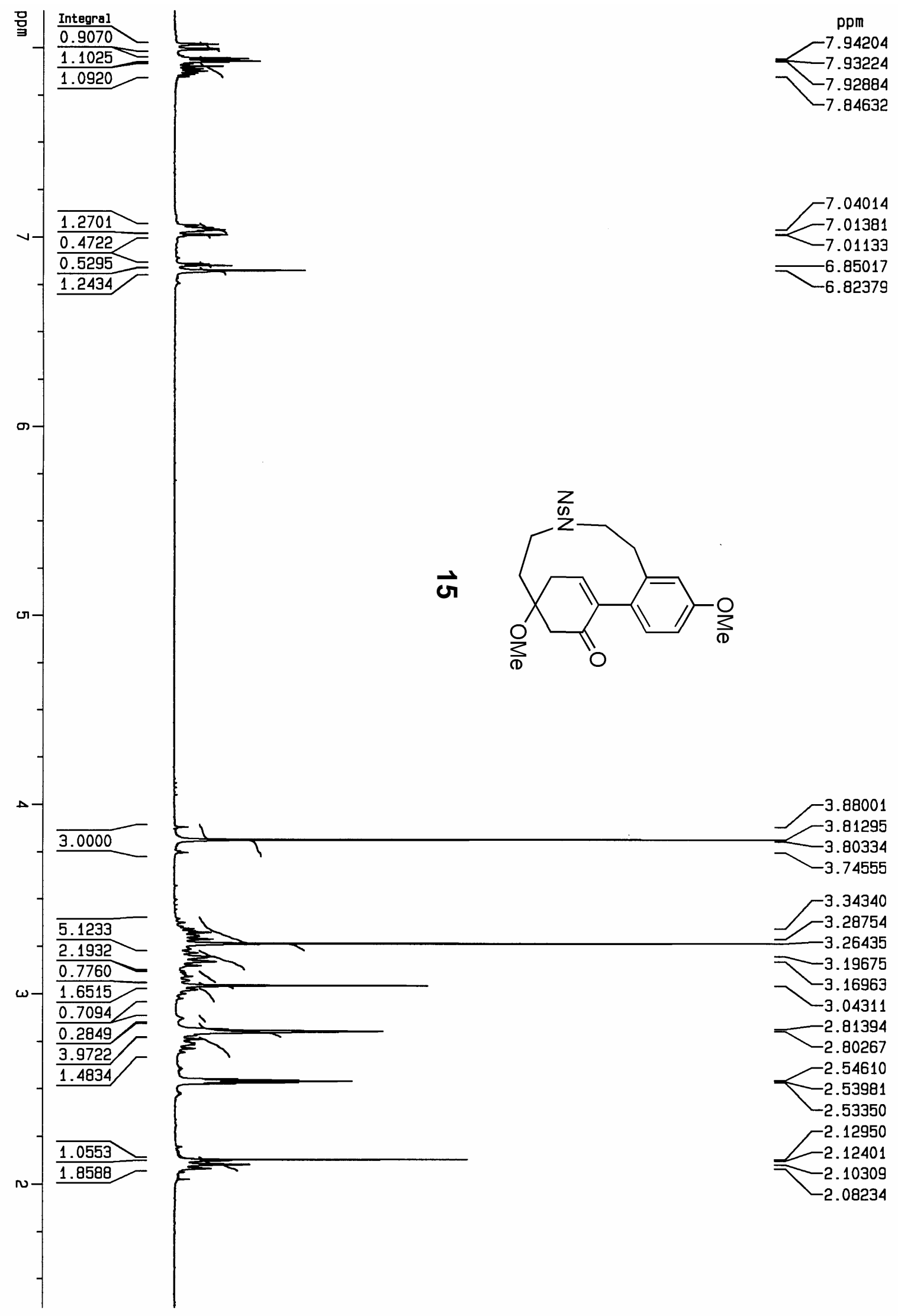




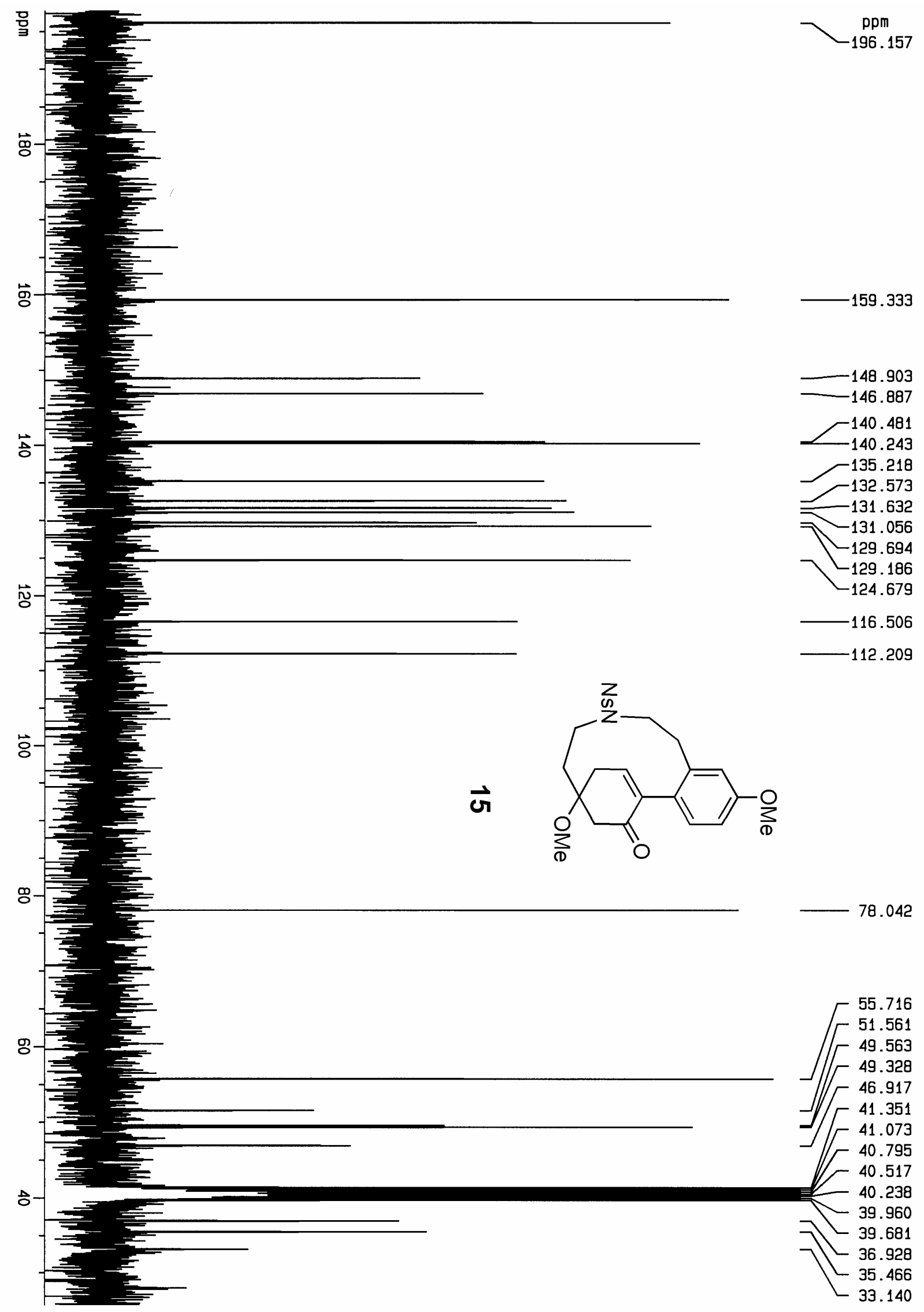




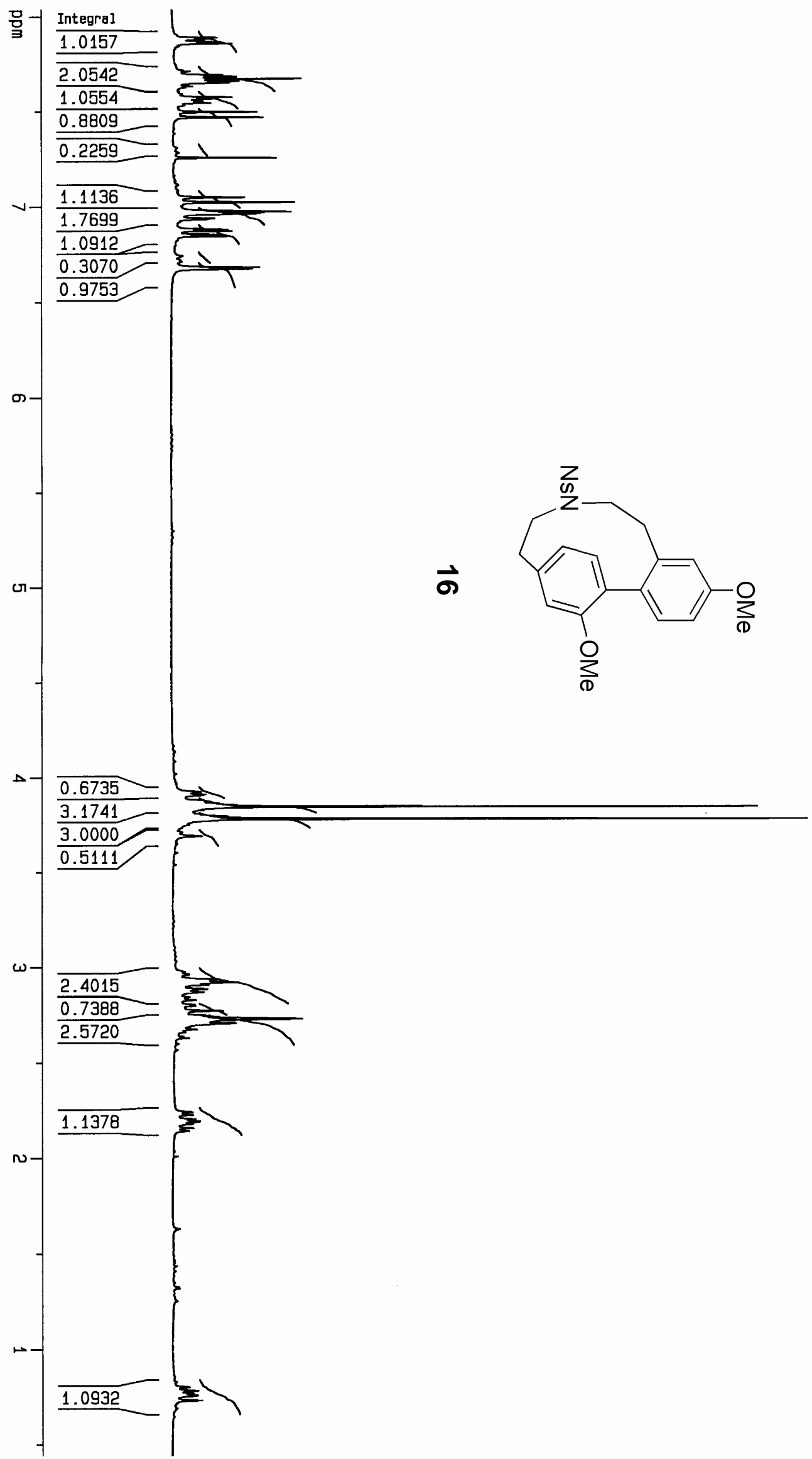

$-7.66005$

$-7.57861$

a) -7.50058

$-7.47321$

$-7.26003$

$-7.05213$

$-7.02582$

6.97595

6.96717

6.87504

6.68470

$-6.67587$

$\approx-5.80709$

$-5.78070$

$-5.74644$

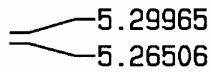

$-4.13432$

$-4.02064$

$-3.92319$

-3.91231

$-3.87409$

3.86510

-3.85726

$-3.84725$

$-3.82841$

$-3.79680$

$-3.78353$

$-3.69233$

2.93420

-2.92401

-2.90957

$-2.88754$

$-2.87212$

$-2.82997$

$-2.80529$

$-2.79833$

$-2.77321$

$-2.74867$

$-2.73158$

寻 -2.70861

-2.67583

$-2.24290$

$-2.22802$

-2.20562

$-2.19450$

$-2.17938$

$-2.15850$

$-1.63182$

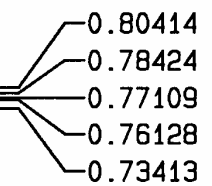


S44

44
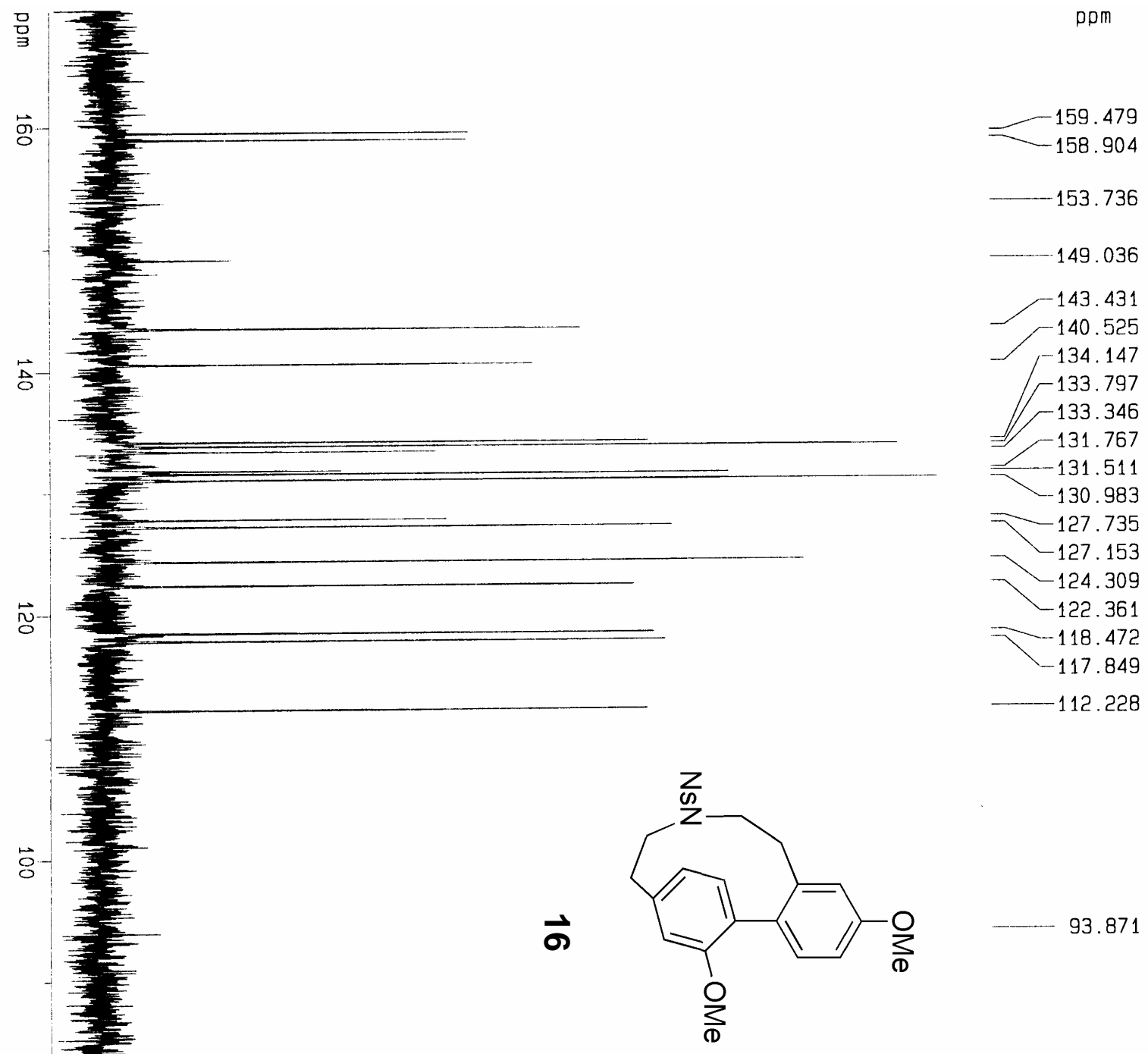

93.871

क

g

59.827
$-\quad 56.200$
$-\quad 55.561$
-50.729

ㅇ

39.193

38.737 


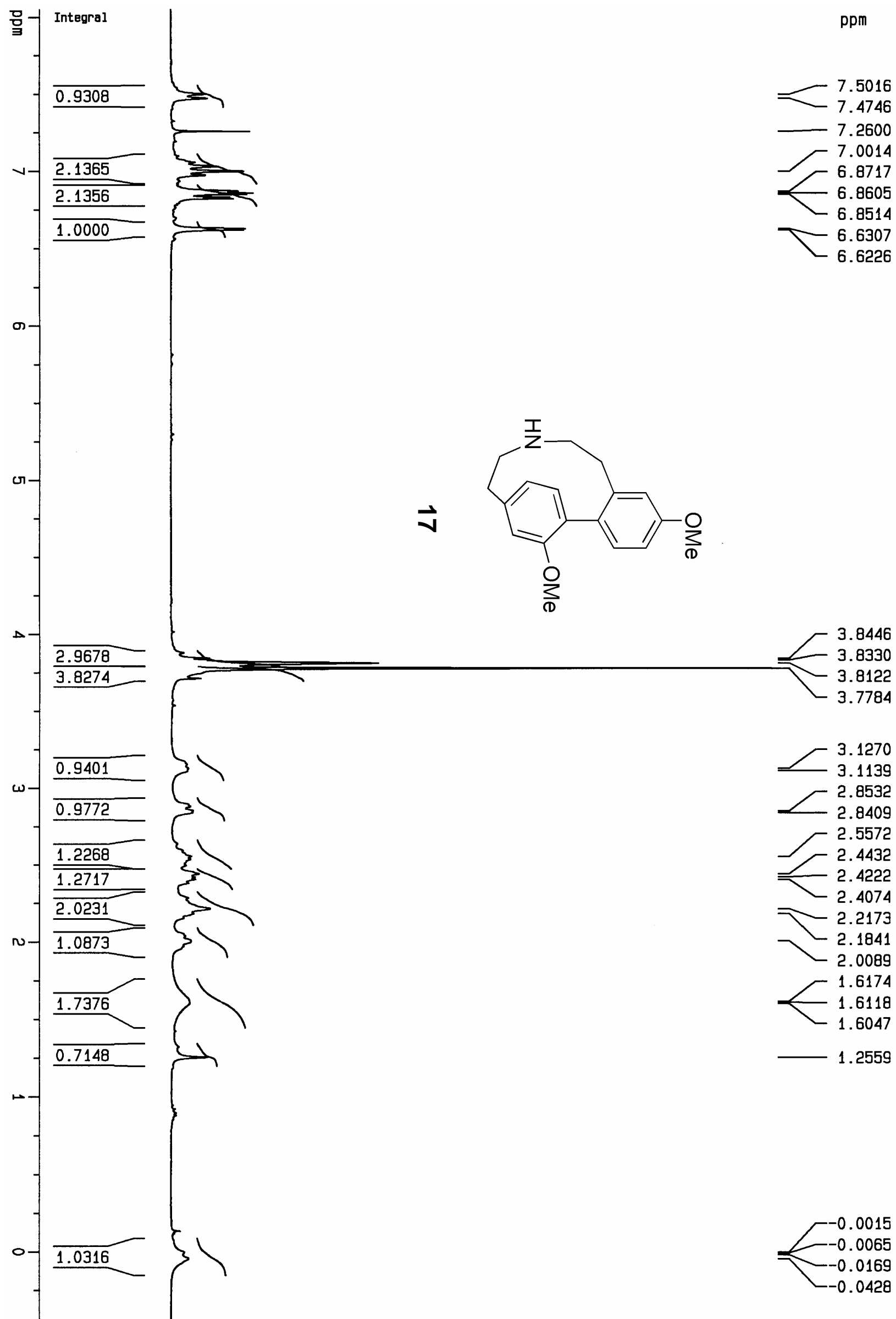



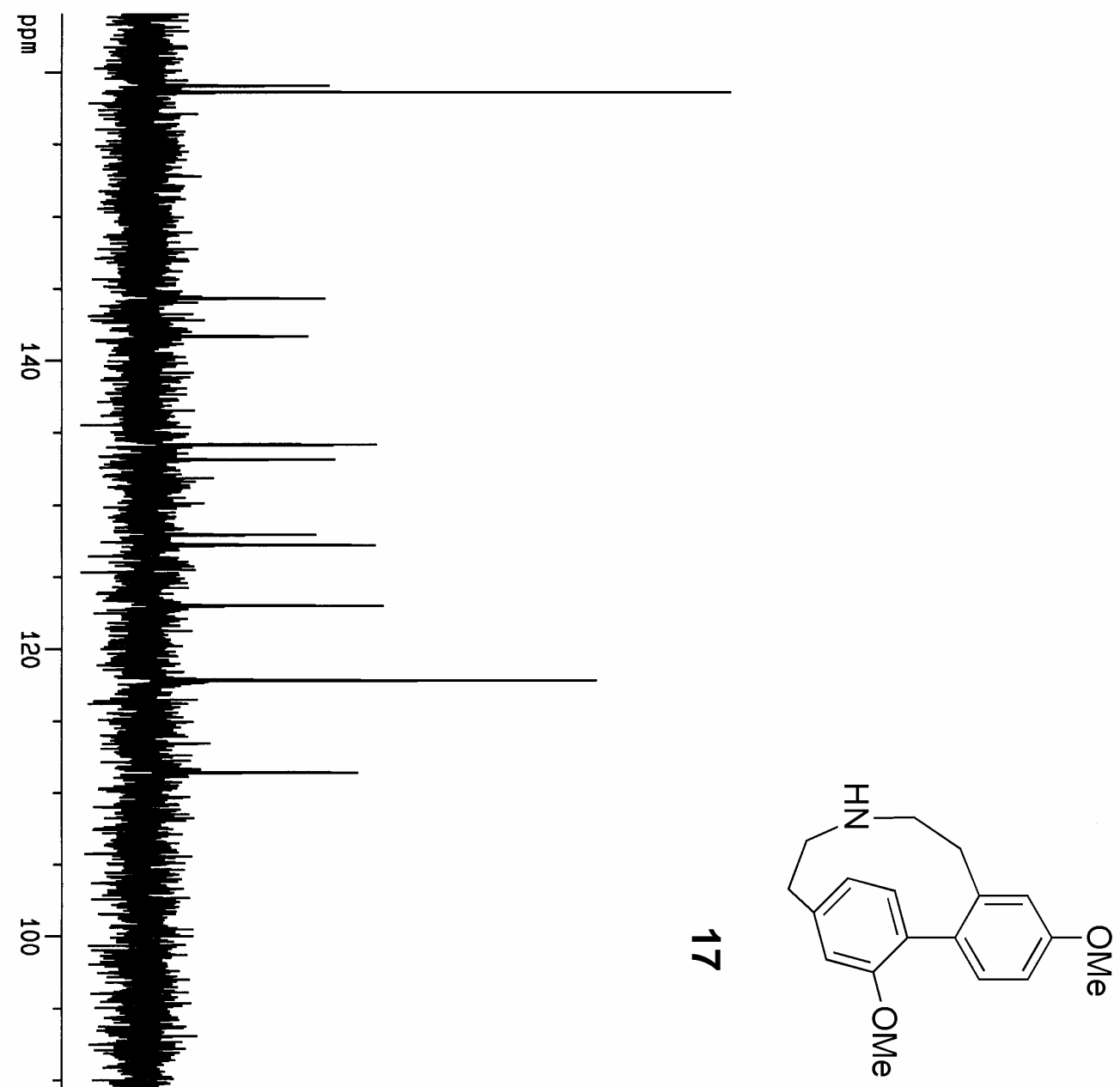

111.418

- 77.586

77.430

77.327

77.296

$-77.229$

$-77.194$

77.162

76.870

$-76.806$

$-76.738$

76.708

g)-

56.422

55.383

53.631

47.218

39.598

39.343 